Article

\title{
Long-Term Changes in the Land-Ocean Ecological Environment in Small Island Countries in the South Pacific: A Fiji Vision
}

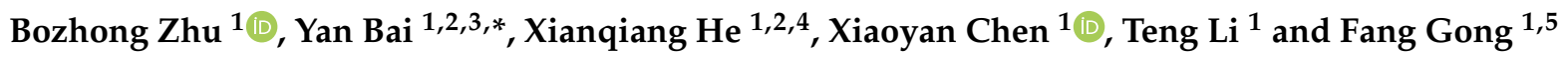 \\ 1 State Key Laboratory of Satellite Ocean Environment Dynamics, Second Institute of Oceanography, \\ Ministry of Natural Resources, Hangzhou 310012, China; bozhongzhu@sio.org.cn (B.Z.); \\ hexianqiang@sio.org.cn (X.H.); chenxy@sio.org.cn (X.C.); liteng@sio.org.cn (T.L.); gongfang@sio.org.cn (F.G.) \\ Southern Marine Science and Engineering Guangdong Laboratory, Guangzhou 510000, China \\ 3 School of Oceanography, Shanghai Jiao Tong University, Shanghai 200030, China \\ 4 Ocean College, Zhejiang University, Zhoushan 316000, China \\ 5 National Earth System Science Data Center, Beijing 100101, China \\ * Correspondence: baiyan@sio.org.cn
}

Citation: Zhu, B.; Bai, Y.; He, X.; Chen, X.; Li, T.; Gong, F. Long-Term Changes in the Land-Ocean Ecological Environment in Small Island Countries in the South Pacific: A Fiji Vision. Remote Sens. 2021, 13, 3740. https://doi.org/10.3390/ rs13183740

Academic Editor: Ali Khenchaf

Received: 30 July 2021

Accepted: 8 September 2021

Published: 18 September 2021

Publisher's Note: MDPI stays neutral with regard to jurisdictional claims in published maps and institutional affiliations.

Copyright: (c) 2021 by the authors. Licensee MDPI, Basel, Switzerland. This article is an open access article distributed under the terms and conditions of the Creative Commons Attribution (CC BY) license (https:// creativecommons.org/licenses/by/ $4.0 /$ )

\begin{abstract}
Small island countries in the South Pacific are ecologically fragile areas, vulnerable to climate change, and the long-term ecological changes in the sea and land have an important impact on their sustainable development. This study takes Fiji, a typical small island country in the South Pacific, as an example, to analyze the change and connection of marine and terrestrial ecosystem environments based on 30 years of multi-source, satellite, remote-sensing data. From 1991 to 2019, according to the change in forest area in Fiji, three stages were delineated: first was a period of stability, then a decrease, and then a recovery in recent years. From 1991 to 2002, Fiji's vegetation accounted for $73 \%$ of the total area; sea environment surrounding the islands, such as sea level height and sea surface temperature, were relatively low, with high water transparency. From 2002 to 2014 , with the development of forestry and tourism, vegetation decreased by $6.89 \%$ and bare land increased, which changes the runoff erosion in the drainage basin; correspondingly, the chlorophyll a concentration in three major estuaries was found to be slightly increased with low water transparency. Meanwhile, coupled with the rising sea temperature, the area of Fiji's coral reefs shrank significantly, with $51.13 \%$ of the total loss of coral reefs occurring in the Vanua Levu, where bare land and runoff were more distributed in its drainage basin. From 2014 to 2019, Fiji's vegetation and coral reef areas recovered from the former stage; affected by short-term climate oscillations such as El NiñoSouthern Oscillation (ENSO), the sea surface temperature showed a significant abnormal drop and the water transparency decreased. In the past 30 years (1993-2018), the sea level rise rate around Fiji reached $4 \mathrm{~mm}$ /year, and the temperature increased by $0.3{ }^{\circ} \mathrm{C}$, which threatens the coastal ecosystem environment, including coral reefs and mangrove; inappropriate land-use change would worsen the situation in these ecologically fragile areas.
\end{abstract}

Keywords: small island countries in the South Pacific; global climate change; land-sea interaction; satellite remote sensing; Fiji

\section{Introduction}

In July 2020, the United Nations released the "Sustainable Development Goals Report 2020", which specifically pointed out that climate change and human activities have had a huge impact on the Earth's ecological environment, which, in turn, has had a negative effect on the natural ecosystem and the sustainable development of a human economic society [1]. The report pointed out that, by the end of the 21st century, the air temperature is expected to rise by $3.2{ }^{\circ} \mathrm{C}$, far exceeding the maximum $1.5^{\circ} \mathrm{C}$ target required by the Paris Agreement. This excessive increase means that the sea temperature and sea level height will continue to rise, the frequency and severity of natural disasters will continue to increase, marine and terrestrial ecosystems will be damaged, and the sustainable development of 
humanity will be affected. Faced with the threat of climate change and human activities having a negative impact on the ecological environment, we need to strengthen the ability to make long-term observations of these changes and better our understanding of the interaction mechanism, in order to provide scientific support for follow-up management decision-making on related issues. For some countries and regions that are more vulnerable to global warming and lack adaptive capacity, the impact of global climate change will far exceed their coping capacity [2].

The small island countries in the South Pacific include 27 countries and regions and consist of more than 10,000 islands. Excluding Australia and New Zealand, the small island countries in the South Pacific are geographically characterized by being surrounded by the sea and being tiny in land area, and most are "ecologically fragile regions" [3]. Their ecological systems have high sensitivity and low stability because islands are one of the fastest responding and most sensitive interfaces between global changes and the various dynamics of land and sea [4]. Such changes include the increase in tropical cyclone intensity, rising sea levels, and the increasing frequency of floods, storm surges and extreme weather events [5].

On the other hand, the small island countries in the South Pacific have a beautiful environment, rich natural resources, and unique tourism, forestry, fishery, and mineral resources, giving the South Pacific region great development potential [6]. In the last 20 years, the economy of the small island countries in the South Pacific has developed rapidly based on natural resources; however, with unreasonable exploitation, the local ecological environment has also been seriously damaged [3]. The coupling of various pressures such as human activities and natural disasters caused the ecological environment of the small island countries in the South Pacific to exhibit complex and diverse fragile sensitivities, which have greatly affected the survival and development of the region, restricting its promotion of sustainable development [7].

Satellite-based real-time and long-term monitoring of land-use changes will help us: (1) understand the layout of land resources and land-use structure, (2) analyze its existing problems and the value of ecosystem services, and (3) monitor and understand whether human activities are reasonable [7-11]. Meanwhile, monitoring the long-term changes in the environmental parameters of coastal waters is one main means of understanding landsea interactions and changes in the ecological environment. Sealey [12] (2004) measured water environment parameters such as water temperature, salinity, total nitrogen level, total phosphorus content, turbidity, and dissolved oxygen saturation in the surrounding waters of islands with different development levels in the central Bahamas, and explored the relationship between island development density and coastal marine ecological environment health. The study results found that the area of coral reefs and seaweed decreased significantly with the increase in development density, and emphasized the importance of coral reefs in assessing the impact of island development on the coastal marine ecological environment McCubbin, et al. [13] showed that climate change, especially sea-level rise, has a negative impact on the supply of clean, fresh water, household economy, food security and human production in the Pacific Island country of Fiji.

Ecologically fragile regions are also called the ecological ecotone, which refers to the transitional area between two different types of ecosystems [14]. Research into the ecological environment of coastal areas such as island countries in the South Pacific necessarily requires an interactive analysis of both land and sea areas. Devlin, et al. [15] focused on the water quality data in the surrounding seas of Vanuatu, a South Pacific Island country, and found that the water quality of the waters surrounding Vanuatu was getting worse and at risk of eutrophication, which was mainly due to the input of pollution from land-based sources such as sewage, industrial discharges and sediments from coastal areas into the offshore area with runoff. Ellison and Fiu [16] found that coral reefs and mangroves in Fiji were affected by climate changes such as the rise in sea level and water temperature, resulting in the degradation of coral reefs and mangrove ecosystems, where rising sea level caused coastal sediments to move offshore, leading to the suffocation of coral reefs, and 
disrupting the salinity and inundation frequency of mangrove habitats, destroying their habitats, while the rising water temperature exposed corals to high water temperatures, disrupting their algal symbiosis and eventually causing bleaching. Gilby, et al. [17] concluded that many threats to coral reefs and other ecosystems in coastal areas are mainly due to human activities, and the overexploitation of habitats and watersheds. Serious pollution emissions would lead to a reduction in biodiversity and increase in sediment and nutrient input, thereby increasing the risk of eutrophication in offshore waters and damaging marine ecosystems. Woesik, et al. [18] found that when sudden, short-term climate oscillations occur, especially in the case of El Niño events, coral reef ecosystems are greatly damaged by exposure to abnormally high temperatures, and the resilience of coral reefs is also reduced due to the low cover of the damaged coral populations. Chin, et al. [19] integrated regional and national report information and found that most coral reefs in the Pacific Ocean remain healthy as a whole, but, in some areas, coral reefs were suffering varying degrees of damage due to environmental and human factors. In general, previous studies on the environmental changes in coastal areas such as the small island countries in the South Pacific have mainly focused on individual ecological environmental factors or the status of certain types of factor; there have been few studies conducting a multi-factor comprehensive analysis of the ecological environment in the small island countries in the South Pacific under the combined effects of climate change and human activities.

This study focuses on Fiji, an island country located in the center of the Southwest Pacific, with a strong economy and rapid development, as well as a high influence from climate change and human activities [20]. First, we report data on 30 years of changes in land use in Fiji from 1991 to 2019, and the water environment from 1993 to 2019, based on multi-source satellite remote-sensing data. Second, we analyze the interactions and relationship between sea and land ecosystem changes to further understand the ecological environmental pressure faced by the small island countries in the South Pacific. Finally, we discussed the impact of global climate change and human activities on the ecological environment of small island countries in the South Pacific to help better understand the sustainable development of islands.

\section{Materials and Methods}

\subsection{Study Area}

Fiji is located in the center of the Southwest Pacific north of New Zealand, east of Vanuatu, and west of Tonga $\left(15^{\circ} \mathrm{S}-22^{\circ} \mathrm{S} ; 175^{\circ} \mathrm{E}-178^{\circ} \mathrm{W}\right)$ (Figure 1), with a land area of $1.83 \times 10^{4} \mathrm{~km}^{2}$ and a maritime exclusive economic zone of $129 \times 10^{4} \mathrm{~km}^{2}$. Fiji is composed of 332 islands including the two biggest islands of Viti Levu and Vanua Levu. Fiji enjoys a tropical oceanic climate, and the temperature remains $22-32{ }^{\circ} \mathrm{C}$ all year round. The distribution of rainfall is uneven, with abundant rainfall in the southeast, and is relatively dry in the western areas [21].

Natural resources are abundant in Fiji, with an average forest area of $9350 \mathrm{~km}^{2}$, of which about $2500 \mathrm{~km}^{2}$ are valuable for exploitation. Fiji is an important global exporter of hardwood and pine. As an island country, Fiji also has rich fishery resources, coral reefs, and mangrove resources. Fiji has many historical sites and rich tourism resources [21], making the tourism industry a very important pillar industry in Fiji.

In this study, the coral reefs around the Fiji Islands were used as the boundary of the islands and adjacent seas. To avoid the omission of small coral reef areas, we simply extended the study boundary to $10 \mathrm{~km}$ away from the coastal line and used this sea area as the study area for the water's environmental parameters. 

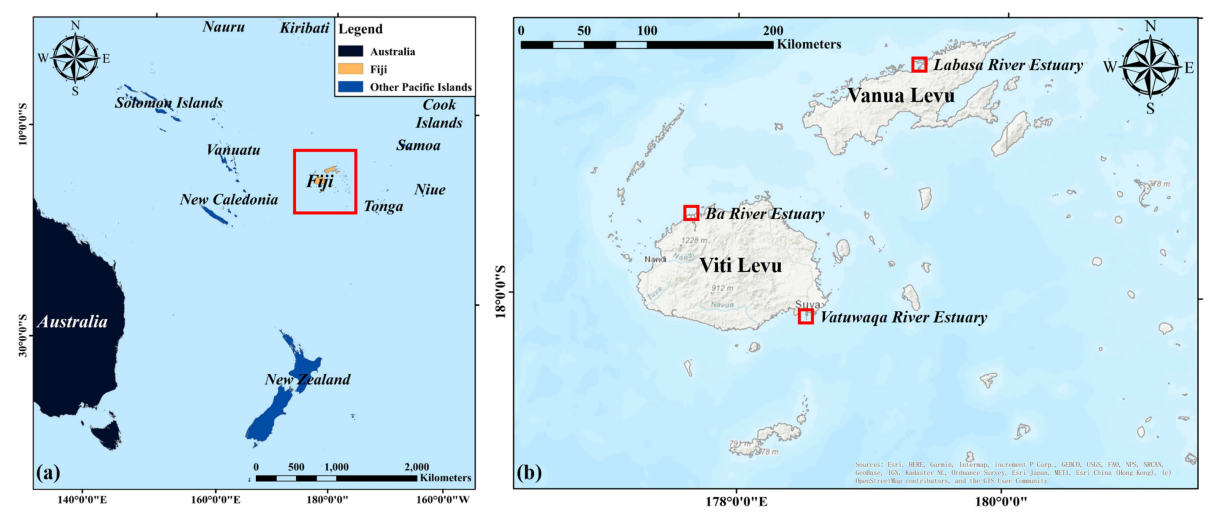

Figure 1. Location of study area (a) and two largest islands in Fiji: Viti Levu and Vanua Levu (b). The red box area in (b) shows the estuaries of the three largest rivers entering the sea in Fiji. Geographic map was obtained from Environmental Systems Research Institute: http:/ / www.esri.com (accessed on 28 August 2020).

\subsection{Data}

\subsubsection{Satellite Data for Island Land}

Remote-sensing images of land in the study area came from the Landsat series data released by the United States Geological Survey (USGS). After examining all the data from 1991 to 2019, there were 30 Landsat Level-1 data covering Fiji (Path and row: 073071, 074071, 074072, 074073 and 075072, respectively) with cloud cover below $20 \%$. The time interval of the acquisition of remote-sensing images in the same period was 1 year. In 1991, due to the lack of data with path and row numbers of 074072 and 075072 , the cloud cover threshold was individually expanded, with a cloud cover of 30\% and 37\%, respectively, in the same period. This expanded cloud coverage in 1991 turned out to have little influence on the classification of land cover after testing. In total, 32 Landsat images were used in this study and, according to the data acquisition time, this study divided the Landsat images covering 1991-2019 into eight stages: 1991, 2002, 2004, 2005, 2011, 2014, 2016 and 2019; their specific information is given in Appendix A Table A1. There are no data in the scene image (Path and row: 073071) covering the islands on the eastern border of Fiji, but the land area covered by this image is very small, and its impact on the final land cover classification results can be ignored; therefore, this area was not considered in this study.

\subsubsection{Satellite Data for the Water Environment}

We used the satellite data from the Marine Satellite Online Analysis Platform (SatCO2), released by the State Key Laboratory of Satellite Ocean Environment Dynamics (SOED), Second Institute of Oceanography, Ministry of Natural Resources, China (http:/ / www. satco2.com (accessed on 4 September 2021)). The SatCO2 platform provide online services for long-time series and massive multi-source remote-sensing data, including the reprocessing of specific satellite products and collections of satellite data from various open data resources around the world, by archiving them with a unified format. It also realizes the online analysis of multi-source data through a three-dimensional (3D) visualization platform. This study aims to analyze the changes in ocean environmental parameters. We chose widely used satellite products, including sea surface chlorophyll a concentration (Chla) (January 1998-December 2018), absorption coefficient of colored dissolved organic matter (aCDOM) (January 1998-December 2019), water transparency/secchi disk depth (SDD) (January 1998-December 2019), partial pressure of atmospheric carbon dioxide (pCO2-atm) (January 2000-December 2016), sea surface temperature (SST) (January 1993-December 2018), and abnormal sea level height (January 1993-December 2017), with specific information presented in Table 1. 
Table 1. Detailed information table of water environment parameters.

\begin{tabular}{|c|c|c|c|c|c|}
\hline Parameter & Time Frame & Unit & $\begin{array}{c}\text { Spatial } \\
\text { Resolution }\end{array}$ & $\begin{array}{l}\text { Temporal } \\
\text { Resolution }\end{array}$ & Dataset \\
\hline Abnormal Sea level & $\begin{array}{c}\text { January } \\
\text { 1993-Decemeber } 2017\end{array}$ & $\mathrm{~m}$ & $25 \mathrm{~km}$ & $\begin{array}{l}\text { monthly } \\
\text { averages }\end{array}$ & CEMES_SAT_MERGE_GLOBAL \\
\hline $\begin{array}{l}\text { Sea surface } \\
\text { temperature }\end{array}$ & $\begin{array}{c}\text { January } \\
\text { 1993-December } 2018\end{array}$ & ${ }^{\circ} \mathrm{C}$ & $25 \mathrm{~km}$ & $\begin{array}{l}\text { monthly } \\
\text { averages }\end{array}$ & NOAA_NOAA_AVHRR_GLOBAL \\
\hline $\begin{array}{l}\text { Atmospheric carbon } \\
\text { dioxide pressure }\end{array}$ & $\begin{array}{c}\text { January } \\
\text { 2000-December } 2016\end{array}$ & ppm & $25 \mathrm{~km}$ & $\begin{array}{l}\text { monthly } \\
\text { averages }\end{array}$ & NOAA_MERGE_MERGE_GLOBAL \\
\hline $\begin{array}{l}\text { Chlorophyll a } \\
\text { concentration }\end{array}$ & $\begin{array}{c}\text { January } \\
\text { 1998-December } 2018\end{array}$ & $\mathrm{mg} / \mathrm{m}^{3}$ & $4 \mathrm{~km}$ & $\begin{array}{l}\text { monthly } \\
\text { averages }\end{array}$ & ESACCI_SAT_MERGE_GLOBAL \\
\hline $\begin{array}{l}\text { Colored dissolved } \\
\text { organic matter } \\
\text { Water transparency }\end{array}$ & $\begin{array}{c}\text { January } \\
\text { 1998-December } 2019\end{array}$ & $\begin{array}{c}\mathrm{m}^{-1} \\
\mathrm{~m}\end{array}$ & $9 \mathrm{~km}$ & $\begin{array}{l}\text { monthly } \\
\text { averages }\end{array}$ & $\begin{array}{l}\text { SIO_SeaWiFS_SeaWiFS_GLOBAL } \\
\text { SIO_MODIS_MODIS_GLOBAL }\end{array}$ \\
\hline
\end{tabular}

Chla, aCDOM, and SDD were used to indicate water quality. We used the Chla products from the Climate Change Initiative (CCI) dataset of the European Space Agency (ESA) (https: / / www.oceancolour.org/ (accessed on 4 September 2021)). CCI data were mainly calculated by combining monthly fusion information of MERIS, MODIS/Aqua, SeaWiFS local area coverage (LAC) and global area coverage (GAC), and VIIRS products and using mixed algorithms (involving OCI, OC5, and OC 3 algorithms). The aCDOM products are generated by a semi-analytical remote-sensing algorithm proposed by Bai et al. [22,23], which was developed using the total absorption coefficient and particle backscattering coefficient of total organic matter through spectral remote-sensing reflectivity with the algorithm of Lee et al. [24]. It then derives the absorption coefficients of CDOM and debris from the total absorption coefficient. SDD is based on the semi-analytical algorithm of $\mathrm{He}$ et al. [25-27], which is calculated using absorption coefficient, backscattering coefficient of particles, and remote-sensing reflectivity at $443 \mathrm{~nm}$. The remote-sensing reflectance data input into the aCDOM and SSD algorithms are from NASA's SeaWiFS and MODIS/Aqua satellites (https: / / oceancolor.gsfc.nasa.gov / (accessed on 4 September 2021)).

Sea-level anomaly products were directly downloaded from Copernicus Marine Environmental Monitoring Center (CMEMS) (http:/ / marine.copernicus.eu/services-portfolio/ access-to-products / (accessed on 4 September 2021)). The product was processed by a SL-TAC multi-task altimeter data-processing system and interpolated at the intersection position and date with the data of Sentinel-3A, Jason-3, HY-2A, Saral/AltiKa, Cryosat-2, OSTM/Jason-2, Jason-1, Topex/Poseidon, Envisat, GFO, and ERS-1/2 satellites. Sea-level anomaly data were derived from the sea-level height (SSH) and mean sea-level height (MSS) [28-30].

Sea-surface temperature products were directly downloaded from the National Oceanic and Atmospheric Administration (NOAA) OISST dataset (https: / / www.ncdc.noaa.gov/ oisst/data-access (accessed on 4 September 2021)). This dataset consists of reanalysis data constructed by combining observation data from different platforms (satellites, ships, and buoys) on a conventional global grid, and interpolation is used to fill in the gaps in the sea temperature map to obtain a complete sea-temperature product [31].

The $\mathrm{CO}_{2}$ mole fraction XCO2 of dry air was downloaded from NOAA Carbontracker (https:/ /www.esrl.noaa.gov/gmd/ccgg/carbontrack (accessed on 4 September 2021)), and then the SatCO2 platform performed the corrections of atmospheric pressure and water vapor pressure on the $\mathrm{XCO}_{2}$ data to obtain atmospheric carbon dioxide pressure data [32-35] 


\subsection{Data Processing}

\subsubsection{Land Use Classification}

We used ENVI 5.3 to perform the preprocessing, such as radiometric calibration and FLAASH atmospheric correction, on the Landsat data. In response to the striping problem of Landsat-7 data [36], additional striping repair operations were performed on Landsat7 data using the Landsat Gapfill plug-in. Then, we used eCognition 8.7 to classify the preprocessed data and evaluate the accuracy of the classification results. Finally, we used the mosaic tool of ENVI 5.3 to mosaic the classified results, which we then trimmed in ArcGIS 10.7 according to the vector layer of the study area to obtain the final classification maps.

Based on the actual situation in Fiji, this study classifies Landsat data into six categories: vegetation, bare land, built-up land, ocean, coral reefs and mangroves (Appendix A Table A2 gives the segmentation scale). The training and verification samples are both selected through visual interpretation, with more than 30 training samples and about $20-25$ verifying samples (verifying samples were obtained by visual interpretation of ultra-high-resolution satellite image data) for each feature type, which were then distributed. Finally, the accuracy assessment tool in eCognition 8.7 was used to verify the accuracy of the classification results. The verification results show that the overall accuracy is higher than $92 \%$, and the Kappa coefficient is higher than 0.90 (Table 2), which indicates that the classification results have a high confidence level.

Table 2. Classification accuracy.

\begin{tabular}{|c|c|c|c|c|c|c|c|c|}
\hline \multirow{2}{*}{ Year } & \multirow{2}{*}{$\begin{array}{l}\text { Overall } \\
\text { Accuracy }\end{array}$} & \multirow{2}{*}{$\begin{array}{c}\text { Kappa } \\
\text { Coefficient }\end{array}$} & \multicolumn{6}{|c|}{ Various Accuracy } \\
\hline & & & Vegetation & Bare Land & Built-Up Land & Ocean & Coral Reef & Mangrove \\
\hline 1991 & $92.68 \%$ & 0.909 & $94.44 \%$ & $93.75 \%$ & $85.71 \%$ & $100.00 \%$ & $85.37 \%$ & $92.54 \%$ \\
\hline 2002 & $94.14 \%$ & 0.929 & $93.18 \%$ & $93.20 \%$ & $87.50 \%$ & $100.00 \%$ & $95.74 \%$ & $92.78 \%$ \\
\hline 2004 & $92.87 \%$ & 0.913 & $92.92 \%$ & $90.70 \%$ & $89.19 \%$ & $97.80 \%$ & $94.57 \%$ & $89.53 \%$ \\
\hline 2005 & $92.77 \%$ & 0.911 & $95.88 \%$ & $92.09 \%$ & $84.21 \%$ & $97.47 \%$ & $97.70 \%$ & $83.33 \%$ \\
\hline 2011 & $93.65 \%$ & 0.923 & $98.72 \%$ & $90.70 \%$ & $83.78 \%$ & $100.00 \%$ & $91.86 \%$ & $91.55 \%$ \\
\hline 2014 & $92.94 \%$ & 0.913 & $92.52 \%$ & $87.25 \%$ & $88.00 \%$ & $100.00 \%$ & $100.00 \%$ & $86.89 \%$ \\
\hline 2016 & $92.01 \%$ & 0.902 & $89.74 \%$ & $91.25 \%$ & $88.68 \%$ & $98.85 \%$ & $95.24 \%$ & $85.45 \%$ \\
\hline 2019 & $93.52 \%$ & 0.921 & $95.35 \%$ & $92.22 \%$ & $86.49 \%$ & $98.63 \%$ & $96.30 \%$ & $87.69 \%$ \\
\hline
\end{tabular}

\subsubsection{Long-Term Changes in Water Environment Data}

We use the time-series analysis function of SatCO2 platform, which allows users to select the region of interest, set a time range of archive data of different parameters, and then analyze the long-term changes. In this study, the Fiji's surrounding waters and the estuary area $(5 \mathrm{~km} \times 5 \mathrm{~km})$ of the three larger rivers in Fiji is selected as the scope of water environmental parameter analysis (Figure 1b). The three rivers are the Ba River in northwest Viti Levu, the Vatuwaqa River in southeast Viti Levu, and the Labasa River in north Vanua Levu. Mangroves and coral reefs both exists in these three estuaries. We set the time range from January 1993 to December 2019 in $\mathrm{SatCO}_{2}$ and output the data file.

\subsection{Evaluation Index of Land-Use Change}

\subsubsection{Land-Use Dynamic Degree}

This study mainly focuses on analyzing the main land feature changes in Fiji over the last 30 years. Therefore, a single land-use dynamic degree is selected to express changes in a certain land-use type within a certain time range in the study area. This single land-use dynamic degree is expressed as an annual rate of change $[8,9,37]$, as follows: 


$$
\mathrm{LC}=\frac{\mathrm{U}_{\mathrm{b}}-\mathrm{U}_{\mathrm{a}}}{\mathrm{U}_{\mathrm{a}}} \times \frac{1}{\mathrm{~T}} \times 100 \%
$$

where $\mathrm{LC}$ is the dynamic degree in a certain period; $\mathrm{U}_{\mathrm{a}}$ and $\mathrm{U}_{\mathrm{b}}$ represent the total area of a certain land use type at the beginning time and end time, respectively; $T$ represents the total time, and the unit of $\mathrm{T}$ in this study is years, to represent the annual change rate.

\subsubsection{Transfer Matrix of Land-Use Type}

The transfer matrix of land-use types can quantitatively describe the conversion process between various types of land use [38,39]. With the overlay analysis in ArcGIS 10.7, we draw the transfer matrix and dynamic change map of land-use types with the following equation:

$$
S_{i j}=\left[\begin{array}{ccc}
S_{11} & \cdots & S_{1 n} \\
\vdots & \ddots & \vdots \\
S_{n 1} & \cdots & S_{n n}
\end{array}\right]
$$

where $S_{i j}$ is the total area of class $\mathrm{i}$ land converted into class $\mathrm{j}$ land in this period.

\section{Results}

\subsection{Land-Use Type Composition}

According to the above-mentioned, object-oriented classification method, a total of six land-use type classifications were obtained in Fiji from 1991 to 2019. As shown in Figure 2, bare land is mainly distributed in the west of Viti Levu and the north of Vanua Levu; mangroves are distributed along the coast of the northwestern Viti Levu and Vanua Levu; offshore coral reefs are mainly distributed in the western and southeastern waters of Viti Levu and the north of Vanua Levu.

The statistical data and percentage accumulation histogram of various land-use types are shown in Table 3 and Figure 3, respectively. Vegetation is the main type of land use in Fiji, accounting for more than $67 \%$ of the total study area, followed by bare land, which accounts for more than $12 \%$. Meanwhile, coral reef, urban and mangrove areas accounted for $11 \%, 1.25 \%$, and $0.97 \%$, respectively.

Table 3. Areas of land-use types in Fiji $\left(\mathrm{km}^{2}\right)$.

\begin{tabular}{cccccccccc}
\hline Year & $\mathbf{1 9 9 1}$ & $\mathbf{2 0 0 2}$ & $\mathbf{2 0 0 4}$ & $\mathbf{2 0 0 5}$ & $\mathbf{2 0 1 1}$ & $\mathbf{2 0 1 4}$ & $\mathbf{2 0 1 6}$ & $\mathbf{2 0 1 9}$ & Mean \\
\hline Vegetation & 14,270 & 14,307 & 14,018 & 13,589 & 13,574 & 13,320 & 13,591 & 14,204 & 13,859 \\
Bare land & 2435 & 2570 & 2988 & 3272 & 3636 & 4030 & 3548 & 2876 & 3169 \\
Built-up land & 140 & 298 & 287 & 258 & 253 & 238 & 202 & 287 & 245 \\
Coral reef & $/$ & 2371 & 1815 & 2157 & 1844 & 2027 & 2241 & 2509 & 2138 \\
Mangrove & 209 & 202 & 211 & 252 & 196 & 216 & 121 & 114 & 190 \\
\hline
\end{tabular}

The average area of vegetation during 1991-2019 in Fiji was 13,859 km² (Table 3). A downward trend was seen from 1991 to 2014, but then an upward trend from 2014 to 2019. In 2014, the vegetation area fell to its lowest level of $13,320 \mathrm{~km}^{2}$, accounting for $67.17 \%$ of the total study area. The average area of bare land during 1991-2019 in Fiji was $3169 \mathrm{~km}^{2}$ (Table 3), which mainly appeared in the west of Viti Levu. The changing trends of bare land were the opposite to those of vegetation. The bare-land area showed an upward trend from 1991 to 2014, which becam-e a downward trend from 2014 to 2019. In 2014, the bare-land area increased to its highest level at $4030 \mathrm{~km}^{2}$, accounting for $20.32 \%$ of the total study area. 

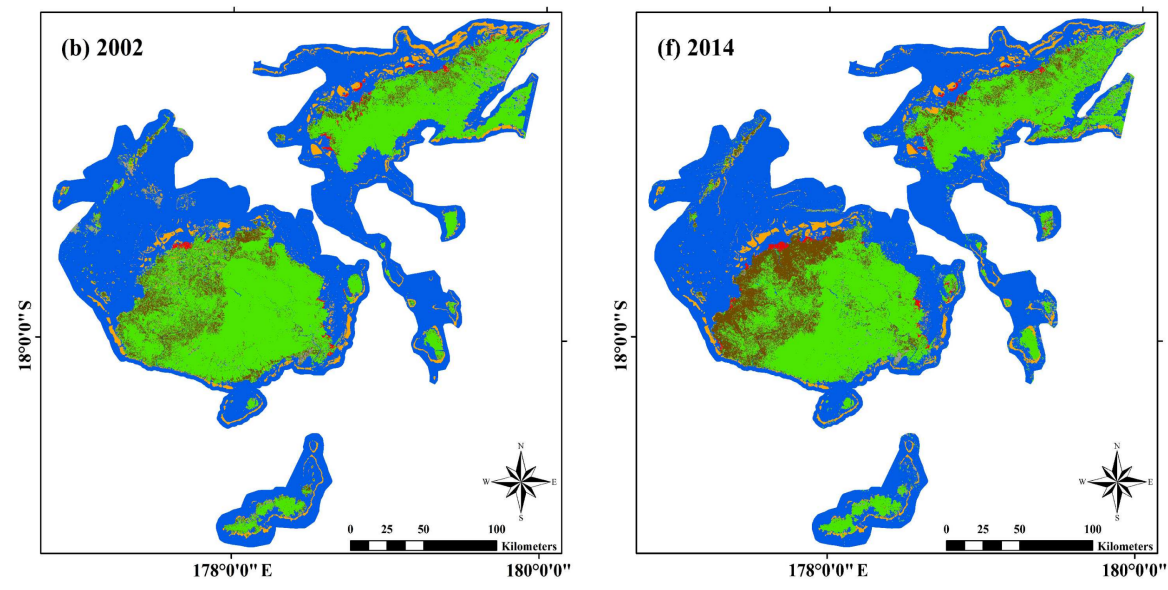

\section{Legend}
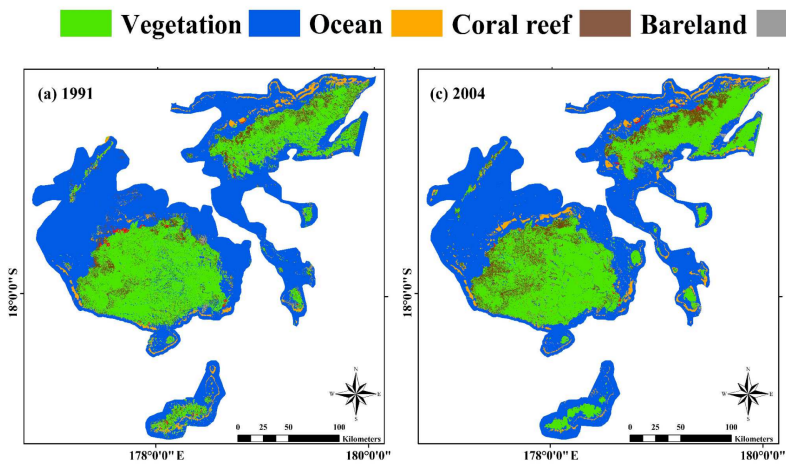

Built-up land Mangrove
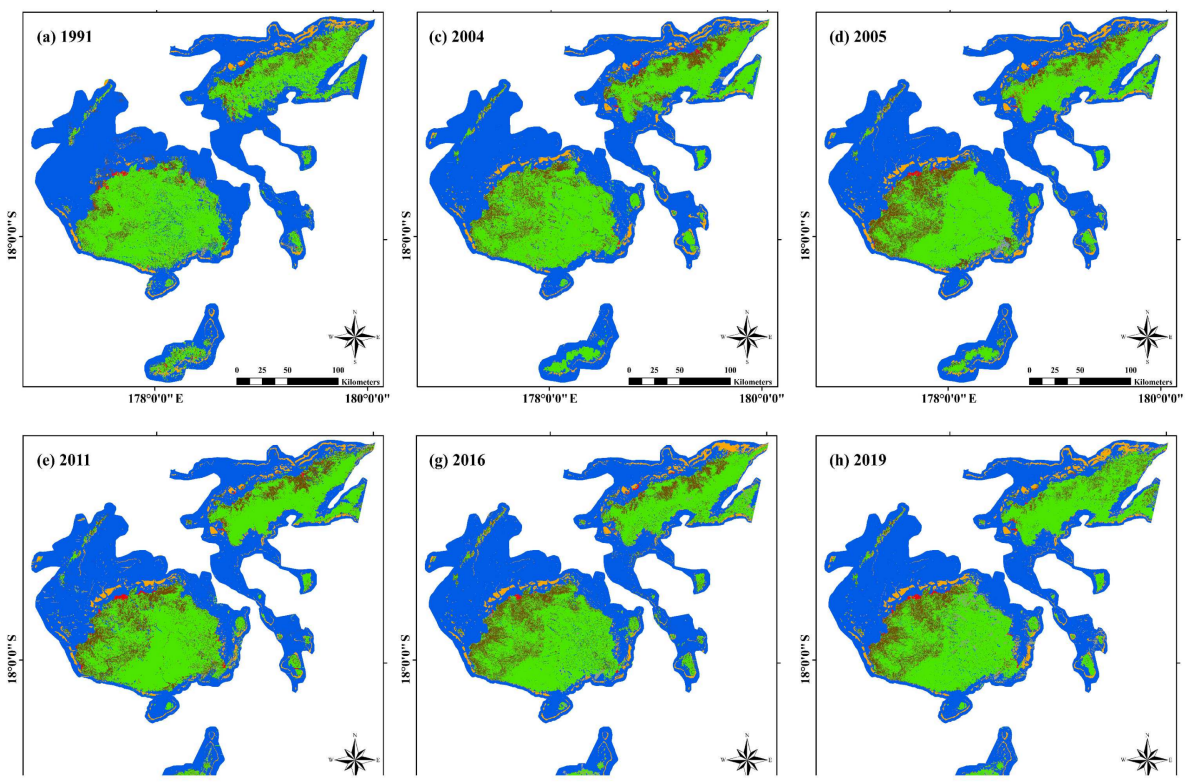

Figure 2. Types of land use in Fiji from 1991 to 2019: (a) 1991; (b) 2002; (c) 2004; (d) 2005; (e) 2011; (f) 2014; (g) 2016; (h) 2019. (Years 2002 and 2014 were selected for enlarged maps because they mark two important turning periods of land-use change in Fiji. Images in 1991 had relatively large cloudiness, which affected the statistics of coral reef area; thus, the statistics of coral reefs area in 1991 were not considered in this study).

The 2002-2019 average area of coral reefs in the seas surrounding Fiji was $2138 \mathrm{~km}^{2}$ (Table 3), and the overall trend first decreased from 2002 to 2011, before increasing after 2011. The coral reef area reached a low level from 2004 to 2014, amounting to $1815 \mathrm{~km}^{2}$ in $2004,1844 \mathrm{~km}^{2}$ in 2011, and $2027 \mathrm{~km}^{2}$ in 2014. The 1991-2019 average area of mangroves in Fiji was $190 \mathrm{~km}^{2}$ (Table 3), which remained relatively stable. After 2016, the mangrove area decreased significantly, falling to $121 \mathrm{~km}^{2}$ in 2016 , and $114 \mathrm{~km}^{2}$ in 2019 . The average built-up land area of Fiji is $245 \mathrm{~km}^{2}$, which was relatively stable over the whole timeframe of the study. 


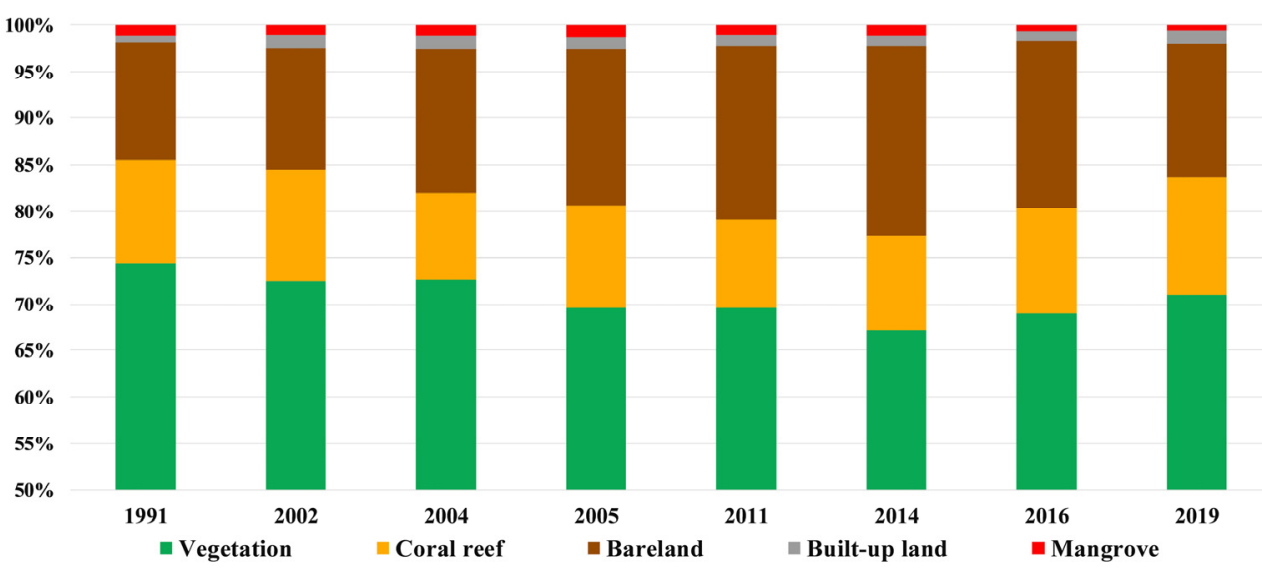

Figure 3. Percentage of stacked land-use types in Fiji from 1991 to 2019. (Coral reef area data in 1991 were replaced by average value).

\subsection{Dynamics Degree and Transfer Changes of Land Use Type}

From 1991 to 2019, the absolute dynamic degree values of various land-use types were ranked as urban, mangrove, bare land, coral reef, and vegetation (Table 4). From 1991 to 2002 , the dynamic degree of vegetation was only $0.02 \%$, indicating that the vegetation area during this period was relatively stable. Meanwhile, the urban dynamic degree reached $9.40 \%$, indicating that the urban area grew rapidly during this period. From 2002 to 2014, the dynamic degree of vegetation was $-0.53 \%$; that is, the vegetation area decreased by about $6.89 \%$ in 13 years, and the dynamic degree of bare land reached $4.37 \%$, that is, the area of bare land increased at a rate of $4.37 \%$ per year. The dynamic degree of coral reefs is $-1.12 \%$, that is, the area of coral reefs is decreasing at a rate of $1.12 \%$ per year. From 2014 to 2019 , the dynamic degree of vegetation was $1.11 \%$, indicating that the vegetation area began to gradually recover. Correspondingly, the dynamic degree of bare land was $-4.77 \%$, indicating that the area of bare land began to decrease. The dynamic degree of coral reefs was $3.96 \%$, indicating that the area of coral reefs also began to gradually recover during this period. Finally, the dynamic degree of mangroves reached $-7.89 \%$, indicating that the area of mangroves decreased significantly during this period. In the last 30 years, the dynamic degrees of urban areas and mangroves had the highest values; however, because these two area types were relatively small, their absolute area change values were smaller than those of vegetation and bare land.

Table 4. Dynamic degree of land-use types in Fiji from 1991 to 2019.

\begin{tabular}{ccccc}
\hline & $\mathbf{1 9 9 1 - 2 0 0 2}$ & $\mathbf{2 0 0 2 - 2 0 1 4}$ & $\mathbf{2 0 1 4 - 2 0 1 9}$ & $\mathbf{1 9 9 1 - 2 0 1 9}$ \\
\hline Vegetation & $0.02 \%$ & $-0.53 \%$ & $1.11 \%$ & $-0.02 \%$ \\
Bare land & $0.46 \%$ & $4.37 \%$ & $-4.77 \%$ & $0.62 \%$ \\
Built-up land & $9.40 \%$ & $-1.55 \%$ & $3.40 \%$ & $3.60 \%$ \\
Coral reef & $/$ & $-1.12 \%$ & $3.96 \%$ & $/$ \\
Mangrove & $-0.29 \%$ & $0.54 \%$ & $-7.89 \%$ & $-1.57 \%$ \\
\hline
\end{tabular}

In general, the vegetation area of Fiji showed significant turns in 2002 and 2014, respectively (Figure 3 and Table 3). Thus, we set years 2002 and 2014 as the panel points to divide the 30-year study time frame into three periods: 1991-2002, 2002-2014, and 2014-2019 to analyze the land-use change.

Vegetation and bare land are two highly correlated land-use types. From 1991 to 2002, the proportion of vegetation remained stable and bare land increased slightly by $5.52 \%$. From 2002 to 2014, the proportion of vegetation area decreased by 6.89\% (an area decrease of $987 \mathrm{~km}^{2}$ ) and the proportion of bareland increased significantly, by $56.81 \%$ (area increase of $1460 \mathrm{~km}^{2}$ ), in 13 years. From 2014 to 2019 , the proportion of vegetation increased by $6.66 \%$ and the bare land decreased by $28.62 \%$, of which $1861 \mathrm{~km}^{2}$ were converted from 
bareland to vegetation. The urban area of Fiji showed an increasing trend during both 1991-2002 and 2014-2019, with the total urban area increasing by $158 \mathrm{~km}^{2}$ and $49 \mathrm{~km}^{2}$, respectively.

In terms of the changes exhibited by coral reefs and mangroves in the surrounding waters, from 2002 to 2014, the proportion of coral reefs decreased by $14.56 \%$ (total area decreased by $344 \mathrm{~km}^{2}$ ); in contrast, the proportion increased by $23.76 \%$ from 2014 to 2019 . The mangrove area in Fiji was relatively stable during 1991-2014, remaining spread across an area of about $200 \mathrm{~km}^{2}$. However, the mangrove areas in 2016 and 2019 were $121 \mathrm{~km}^{2}$ and $114 \mathrm{~km}^{2}$, respectively, and significantly smaller than in other periods.

According to the land-use-type transfer matrix, the land-use-type transfer direction and area diagram, as well as the dynamic change diagram in Fiji, are shown in Figures 4 and 5. During 1991-2019, the transfer of land-use types in Fiji's land area mainly entailed the conversion of vegetation and bare land.

(a) 1991-2002

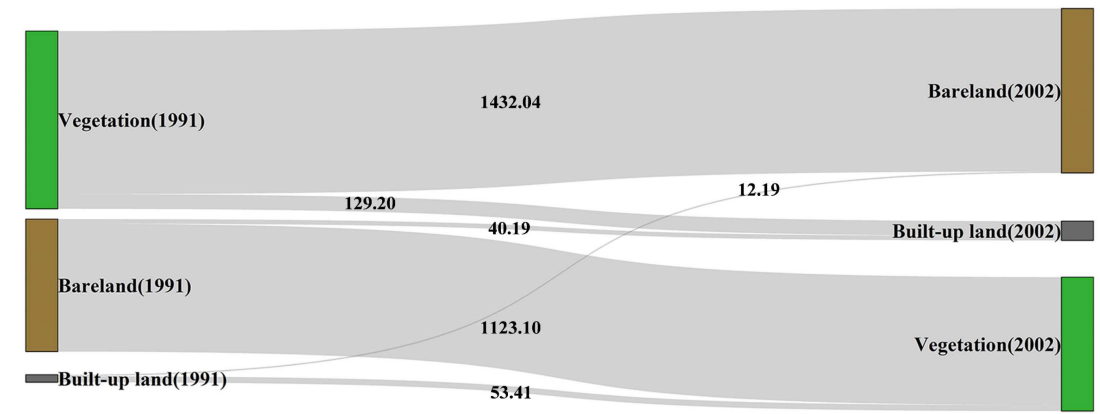

(b) 2002-2014

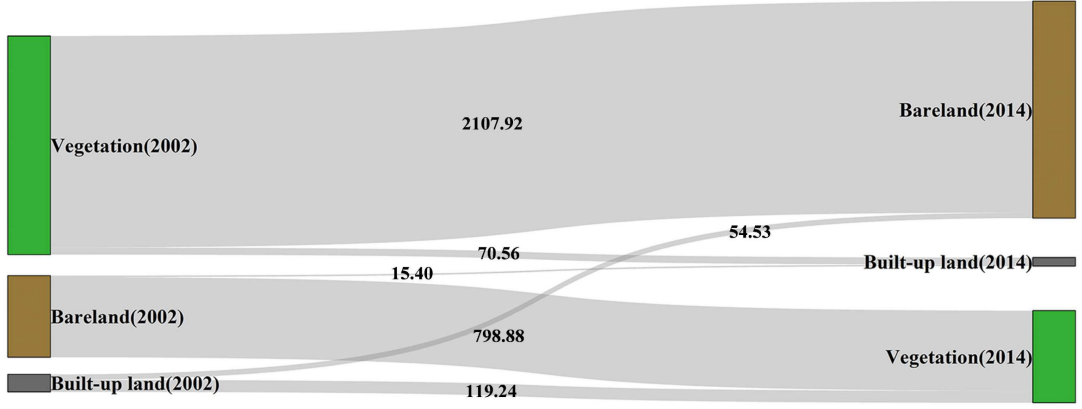

(c) 2014-2019

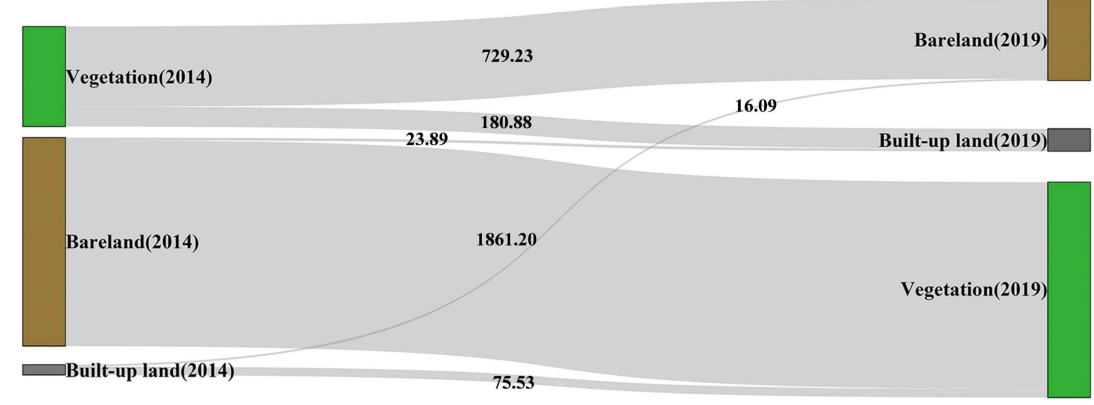

Figure 4. Schematic diagram of the transfer direction and area of land-use types. (a) 1991-2002; (b) 2002-2014 (c); 2014-2019 (The rectangle in the Figure represents the land-use type, where green represents vegetation, brown represents bare land, and dark gray represents the city; the size of the rectangle represents the total area of the transfer; the light gray curve represents the direction of feature transfer, and the thickness and number of curves represent the corresponding transfer direction and area). 
From 1991 to 2002, the transformation area from vegetation to bare land was $1432 \mathrm{~km}^{2}$, which mainly occurred in the western area of Viti Levu, and the area transferred from bare land to vegetation was $1123 \mathrm{~km}^{2}$ (Figure 4a), which mainly occurred on Vanua Levu (Figure 5a). From 2002 to 2014, the area of vegetation transformation to bare land increased further, with a total area of $2108 \mathrm{~km}^{2}$, and the area of bare land transformed to vegetation was $799 \mathrm{~km}^{2}$ (Figure $4 \mathrm{~b}$ ). In addition to the transformation of a larger area of vegetation to bare land in the western region of Viti Levu, Fiji, a certain amount of vegetation land was transformed to bare land on Vanua Levu Island (Figure 5b). From 2014 to 2019, the transformation degree of vegetation to bare land decreased significantly, with a total changed area of $729 \mathrm{~km}^{2}$, which mainly occurred in the northeast area of Vanua Levu. A large area of bare land began to retransform to vegetation, with a total changed area of $1861 \mathrm{~km}^{2}$ (Figure 4c), which mainly occurred in the western area of Viti Levu and northern area of Vanua Levu (Figure 5c).
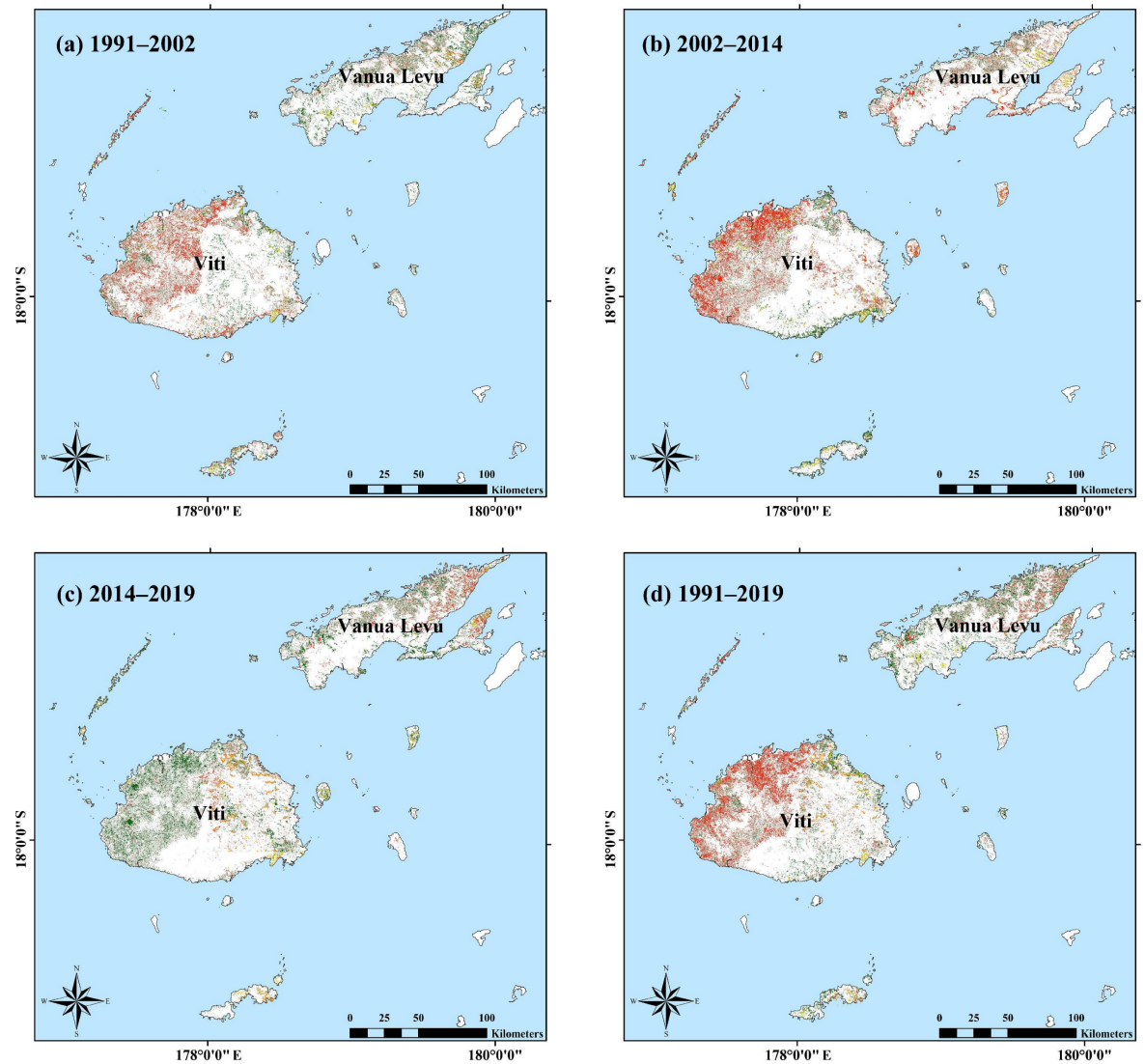

\section{Legend}

\begin{tabular}{l|l|l|l|} 
Vegetation to Bareland & Built-up land to Vegetation & Bareland to Built-up land \\
Vegetation to Built-up land & Built-up land to Bareland & Bareland to Vegetation
\end{tabular}

Figure 5. Dynamic changes in land-use types in Fiji's land area: (a) 1991-2002; (b) 2002-2014; (c) 2014-2019; (d) 1991-2019.

The overall changes in land-use types in the west of Viti Levu were significantly stronger than those in the east, and the changes in the northeast of Vanua Levu were significantly stronger than those in the southwest (Figure $5 d$ ).

\subsection{Environmental Changes in Fiji's Surrounding Waters and Coastal Estuaries}

To understand the interaction between land-use change and marine-water environment change in Fiji, this study selected Fiji's surrounding waters and the coastal estuary area $(5 \mathrm{~km} \times 5 \mathrm{~km})$ of three larger rivers in Fiji, namely, the Ba River in the northwest of 
Viti Levu, the Vatuwaqa River in the southeast of Viti Levu, and the Labasa River in the north of Vanua Levu. There are mangroves and coral reefs in these estuary areas.

The range of the abnormal sea level in the Fiji's surrounding waters was about $-0.02-0.09 \mathrm{~m}$, and, in the three estuaries, it ranged from approximately -0.07 to $0.13 \mathrm{~m}$, with an average value of $0.03 \mathrm{~m}$. The Fiji's surrounding waters and all three areas showed a significant upward trend, $p<0.001$ (Figure 6a and Table 5). During 1993-2017, the sea level rose by about $0.1 \mathrm{~m}$; that is, the sea level rose at a rate of $4 \mathrm{~mm} /$ year. It has been reported that the average rate of global sea-level rise from 2006 to 2015 was $3.6 \mathrm{~mm} /$ year [40]. Thus, the speed of sea-level rise in Fiji was higher than the global average.
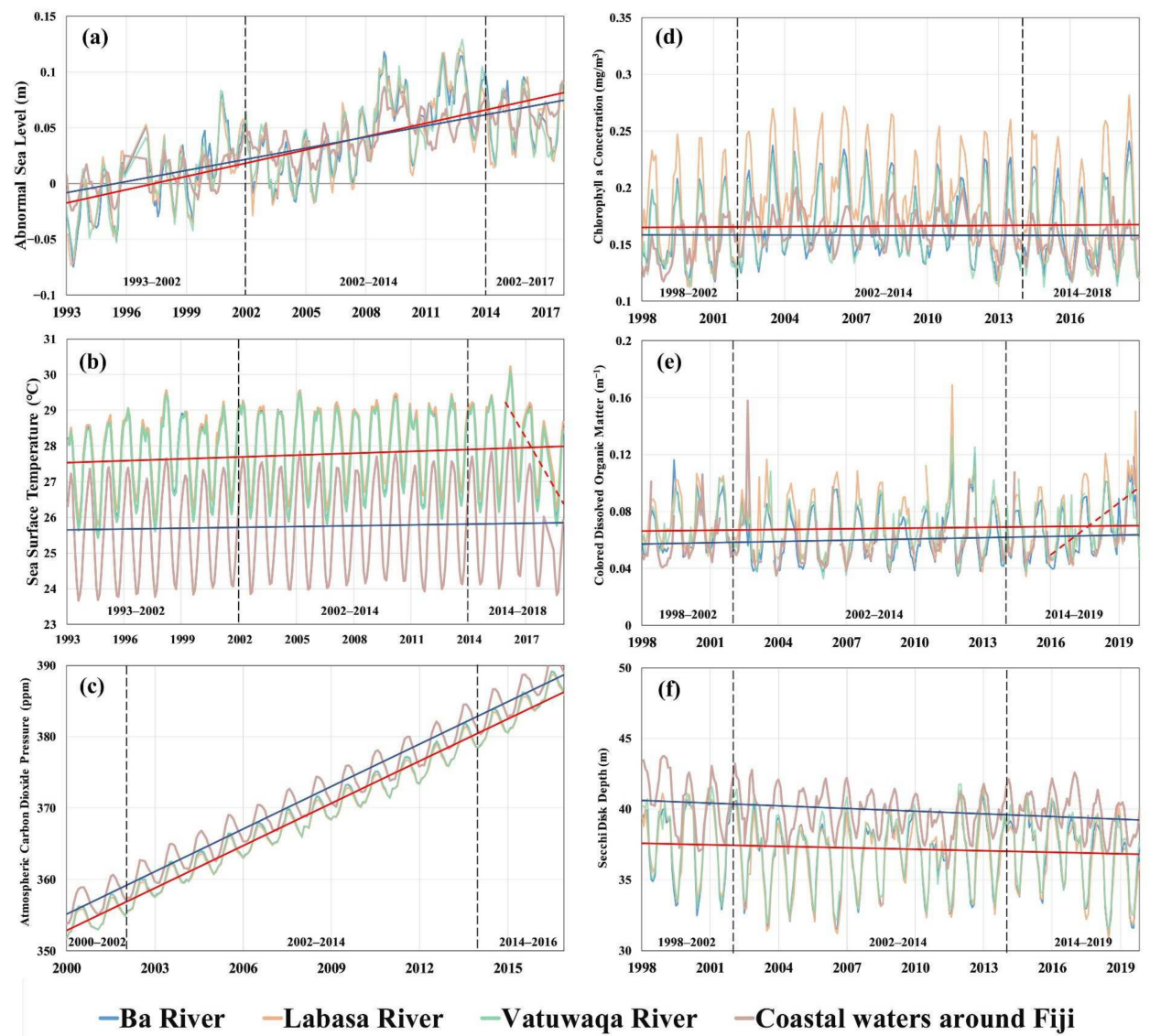

Figure 6. Anomaly chart of long-term variation in water environment parameters: (a) Sea-level anomaly; (b) Sea-surface temperature; (c) Atmospheric carbon dioxide pressure; (d) Chlorophyll a concentration; (e) Absorption of colored dissolved organic matter; (f) Water transparency. The vertical black dotted lines correspond to years 2002 and 2014, respectively. The blue line is the trend line of the coastal waters around Fiji, and the red line is the average trend line of the three estuaries, and the relevant statistics are shown in Table 5. The data in plots (e,f) during January 1998 to December 2002 are from SeaWiFS, and the data covering January 2003 to December 2019 are from MODIS. Compared with other periods, the sea-surface temperature of the three estuaries showed a significant decline from January 2016 to December 2018, and colored dissolved organic matter showed a significant upward trend from January 2016 to December 2019. Therefore, in plots (b,f), additional red dashed lines are used to characterize the special changing trends.

The sea-surface temperature in the Fiji's surrounding waters ranged from $23{ }^{\circ} \mathrm{C}$ to $28^{\circ} \mathrm{C}$, with an average value of $26^{\circ} \mathrm{C}$, and in the three estuaries, it ranged from $25^{\circ} \mathrm{C}$ to $30{ }^{\circ} \mathrm{C}$, with an average value of $28{ }^{\circ} \mathrm{C}$, which was about $2{ }^{\circ} \mathrm{C}$ warmer than coastal waters around Fiji. During 1993-2019, the sea-surface temperature rose continuously $\left(a_{S S T}>0\right.$ ), with an increase of about $0.3^{\circ} \mathrm{C}$ (Figure $6 \mathrm{~b}$ and Table 5). From 2016 to 2018, the sea-surface temperature in the Fiji's surrounding waters and all estuaries of these three 
rivers decreased significantly $(t=-3.4410, p<0.005$, Figure $6 c$ and Table 5$)$, which might

be due to short-term climate oscillations (Section 4.1.2 offers further discussion).

Table 5. Regression statistical analysis of water environment parameters.

\begin{tabular}{|c|c|c|c|c|c|c|c|c|c|}
\hline Parameter & Region & Slope & Intercept & $\mathbf{R}^{2}$ & $t$ & $p$ & Minimum & Maximum & Mean \\
\hline \multirow{4}{*}{$\begin{array}{l}\text { Sea-level } \\
\text { anomaly }\end{array}$} & $\begin{array}{l}\text { Coastal waters } \\
\text { around Fiji }\end{array}$ & $9.15 \times 10^{-6}$ & -0.3191 & 0.7490 & 29.0617 & $<0.001$ & -0.02 & 0.09 & 0.03 \\
\hline & Ba River & $1.35 \times 10^{-5}$ & -0.4861 & 0.4920 & 13.9873 & $<0.001$ & -0.07 & 0.12 & 0.03 \\
\hline & Labasa River & $1.29 \times 10^{-5}$ & -0.4643 & 0.4538 & 12.9560 & $<0.001$ & -0.07 & 0.12 & 0.03 \\
\hline & $\begin{array}{c}\text { Vatuwaqa } \\
\text { River }\end{array}$ & $1.32 \times 10^{-5}$ & -0.4729 & 0.4779 & 13.5990 & $<0.001$ & -0.06 & 0.13 & 0.03 \\
\hline \multirow{4}{*}{$\begin{array}{l}\text { Sea- } \\
\text { surface } \\
\text { tempera- } \\
\text { ture }\end{array}$} & $\begin{array}{c}\text { Coastal waters } \\
\text { around Fiji }\end{array}$ & $1.99 \times 10^{-5}$ & 24.9793 & 0.0018 & 0.7473 & 0.4555 & 23.67 & 28.18 & 25.75 \\
\hline & Ba River & $2.26 \times 10^{-5}$ & 26.7815 & 0.0014 & 0.5411 & 0.5890 & 25.48 & 30.14 & 27.72 \\
\hline & Labasa River & $2.27 \times 10^{-5}$ & 26.9261 & 0.0017 & 0.5901 & 0.5558 & 25.80 & 30.23 & 27.88 \\
\hline & $\begin{array}{l}\text { Vatuwaqa } \\
\text { River }\end{array}$ & $1.97 \times 10^{-5}$ & 26.8231 & 0.0011 & 0.4793 & 0.6323 & 25.43 & 30.08 & 27.66 \\
\hline \multirow{4}{*}{$\begin{array}{l}\text { Atmospheric } \\
\text { carbon } \\
\text { dioxide } \\
\text { pressure }\end{array}$} & $\begin{array}{l}\text { Coastal waters } \\
\text { around Fiji }\end{array}$ & 0.0054 & 156.5292 & 0.9657 & 75.3885 & $<0.001$ & 353.82 & 392.05 & 371.91 \\
\hline & Ba River & 0.0054 & 155.4276 & 0.9747 & 88.2886 & $<0.001$ & 351.69 & 389.17 & 369.46 \\
\hline & Labasa River & 0.0054 & 155.3299 & 0.9790 & 96.9657 & $<0.001$ & 351.67 & 388.67 & 369.23 \\
\hline & $\begin{array}{c}\text { Vatuwaqa } \\
\text { River }\end{array}$ & 0.0054 & 155.4031 & 0.9740 & 86.9195 & $<0.001$ & 351.59 & 389.25 & 369.54 \\
\hline \multirow{4}{*}{$\begin{array}{l}\text { Chlorophyll } \\
\text { a concen- } \\
\text { tration }\end{array}$} & $\begin{array}{c}\text { Coastal waters } \\
\text { around Fiji }\end{array}$ & $-1.7 \times 10^{-8}$ & 0.15911 & $4.72 \times 10^{-6}$ & -0.0343 & 0.9726 & 0.12 & 0.20 & 0.16 \\
\hline & Ba River & $1.41 \times 10^{-6}$ & 0.1120 & 0.0068 & 1.1737 & 0.2419 & 0.12 & 0.24 & 0.17 \\
\hline & Labasa River & $2.33 \times 10^{-6}$ & 0.1006 & 0.0118 & 1.5527 & 0.1221 & 0.11 & 0.28 & 0.19 \\
\hline & $\begin{array}{c}\text { Vatuwaqa } \\
\text { River }\end{array}$ & $6.13 \times 10^{-7}$ & 0.1400 & 0.0014 & 0.5347 & 0.5935 & 0.11 & 0.23 & 0.16 \\
\hline \multirow{4}{*}{$\begin{array}{l}\text { Colored } \\
\text { dissolved } \\
\text { organic } \\
\text { matter }\end{array}$} & $\begin{array}{c}\text { Coastal waters } \\
\text { around Fiji }\end{array}$ & $8.28 \times 10^{-7}$ & 0.0274 & 0.0101 & 1.3523 & 0.1780 & 0.03 & 0.16 & 0.06 \\
\hline & Ba River & $4.70 \times 10^{-7}$ & 0.0814 & 0.0022 & -0.6737 & 0.5013 & 0.03 & 0.12 & 0.06 \\
\hline & Labasa River & $-1.00 \times 10^{-7}$ & 0.1105 & 0.0084 & -1.3104 & 0.1916 & 0.03 & 0.17 & 0.07 \\
\hline & $\begin{array}{c}\text { Vatuwaqa } \\
\text { River }\end{array}$ & $1.22 \times 10^{-7}$ & 0.0630 & 0.0002 & 0.1903 & 0.8493 & 0.03 & 0.13 & 0.07 \\
\hline \multirow{4}{*}{$\begin{array}{c}\text { Water } \\
\text { trans- } \\
\text { parency }\end{array}$} & $\begin{array}{l}\text { Coastal waters } \\
\text { around Fiji }\end{array}$ & -0.0002 & 46.7895 & 0.0639 & -4.2293 & $<0.001$ & 35.77 & 43.71 & 39.92 \\
\hline & Ba River & -0.0001 & 41.2298 & 0.0062 & -1.1227 & 0.2629 & 31.14 & 41.24 & 36.87 \\
\hline & Labasa River & -0.0002 & 42.5351 & 0.0108 & -1.4836 & 0.1395 & 30.74 & 41.46 & 36.77 \\
\hline & $\begin{array}{l}\text { Vatuwaqa } \\
\text { River }\end{array}$ & -0.0001 & 41.3862 & 0.0056 & -1.0673 & 0.2871 & 31.46 & 41.76 & 37.20 \\
\hline
\end{tabular}

Note: regression equation $\mathrm{y}=\mathrm{ax}+\mathrm{b}$, where $\mathrm{a}$ is slope and $\mathrm{b}$ is intercept.

The atmospheric carbon dioxide pressure in Fiji's surrounding waters ranged from $353 \mathrm{ppm}$ to $392 \mathrm{ppm}$, with an average value of $371 \mathrm{ppm}$, and in the three estuaries, it ranged from $351 \mathrm{ppm}$ to $389 \mathrm{ppm}$, with an average value of $369 \mathrm{ppm}$, which was about $2 \mathrm{ppm}$ lower than coastal waters around Fiji. As shown in Figure $6 \mathrm{c}$ and Table 5, the atmospheric carbon dioxide pressure shows a significant upward trend $(p<0.001)$, which increased by about 40 ppm during 2000-2016.

The chlorophyll a concentration in the Fiji's surrounding waters ranged from 0.12 to $0.20 \mathrm{mg} / \mathrm{m}^{3}$, with an average value of $0.16 \mathrm{mg} / \mathrm{m}^{3}$, and in the three estuaries, it ranged from 0.11 to $0.24 \mathrm{mg} / \mathrm{m}^{3}$, with an average value of $0.17 \mathrm{mg} / \mathrm{m}^{3}$. The colored dissolved organic matter in Fiji's surrounding waters ranged from 0.03 to $0.16 \mathrm{~m}^{-1}$, with an average value of $0.06 \mathrm{~m}^{-1}$, and in the three estuaries, it ranged from 0.03 to $0.17 \mathrm{~m}^{-1}$, with an average value of $0.07 \mathrm{~m}^{-1}$. As shown in Figure 6d,e and Table 5, the chlorophyll a concentration and colored dissolved organic matter in three estuaries showed a slight but significant 
upward trend. From 2002 to 2013, the chlorophyll a concentration in the estuary area of each river was slightly higher than that in other periods. At the same time, the chlorophyll a concentration and colored dissolved organic matter content in the estuary of Labasa River were slightly higher than other two rivers.

The water transparency in the Fiji's surrounding waters ranged from 36 to $44 \mathrm{~m}$, with an average value of $40 \mathrm{~m}$, and in the three estuaries, it ranged from 31 to $41 \mathrm{~m}$, with an average value of $37 \mathrm{~m}$, which was about $3 \mathrm{~m}$ lower than coastal waters in Fiji. As shown in Figure $6 \mathrm{f}$ and Table 5 , the decreasing trend of water transparency is not significant $(p>0.1)$. From 2002 to 2013, the water transparency in each estuary was slightly lower than in other periods.

\section{Discussion}

\subsection{Impact of Ecological Environment Change on Surrounding Water}

\subsubsection{Effects of Sea Level and Water Temperature Rise}

The small island countries in the South Pacific are, at present, one of the regions most affected by climate change [41]. At the same time, the small island countries in the South Pacific also have $2.42 \%$ of the world's mangroves, with a total area of about $3437 \mathrm{~km}^{2}$. Although the total area of mangroves in this region accounts for a small proportion of global mangrove areas, each island has an independent mangrove community structure, which is of great significance to the local ecological environment and human activities [42]. Since the start of the 21st century, the average speed of global sea level rises was $3.6 \mathrm{~mm} /$ year, and the data of this study showed that the sea level offshore of Fiji was increasing, with an average speed of about $4 \mathrm{~mm} /$ year (Figure $6 \mathrm{c}$ and Table 5), a rate higher than the global average. It has been reported that land inundation will be one of the main threats facing the small island countries in the South Pacific [7], and also poses a great threat to fragile ecosystems such as mangroves and seagrass beds off the coast. According to the current climate change situation, the physiological threshold of the mangrove ecosystem will be reached within 30 years [43]. At present, the existing literature has proved that the mangrove forests in Tonga, Marshall Islands, Kiribati, Tuvalu and other low-altitude areas have been greatly affected and threatened by the rising sea level. Given that the global climate is still changing, these additional changes will further threaten the balance and stability of the mangrove ecosystem in Fiji, and even across all small island countries in the South Pacific, and then threaten the ecological balance of coastal zones, destroy the local ecological environment, and affect these countries' social and economic development [15,42].

Compared with mangroves, offshore coral reefs were found to be more sensitive to seawater temperature rises, water quality changes, and seawater acidification. There are about $2000 \mathrm{~km}^{2}$ of coral reefs in the offshore waters of Fiji (Table 2), which have provided habitats, spawning grounds, and shelter for marine-living resources in this region, thus making them important natural resources for biodiversity, stability, and the provision of ecosystem services. The sea-surface temperature in the offshore area of Fiji remained between $25^{\circ} \mathrm{C}$ and $30^{\circ} \mathrm{C}$ on average. However, from 1993 to 2019, the sea-surface temperature increased continuously (aSST $>0$ ). Overall, it has risen by about $0.3^{\circ} \mathrm{C}$, which greatly increases the risk of coral reef bleaching and even survival. At present, coral bleaching is widely occurring in some areas of the Pacific Ocean. At the same time, since the industrial revolution, the amount of carbon dioxide in the atmosphere rose gradually by about 1.8 ppm every year [44]. The atmospheric carbon dioxide pressure in Fiji estuary also shows an obvious upward trend, with an increase of $40 \mathrm{ppm}$ in the last 20 years (Table 5, $\left.P_{A C P}<0.001\right)$. As more atmospheric $\mathrm{CO}_{2}$ is absorbed by the ocean, the risk of ocean acidification will amplify. It has been found that if anthropogenic $\mathrm{CO}_{2}$ emissions continue to increase according to the current trend, the average $\mathrm{pH}$ value of the ocean may decrease by 0.5 units by 2100, which will threaten the survival of coral reefs [45].

At present, the relevant literature has evaluated the status of coral reefs in small island countries in the South Pacific, and the assessment results show that since the first coral reef risk assessment was conducted in 1998, the number of threatened coral reefs 
has increased by $60 \%$, and the area of coral reefs classified as facing a medium or higher risk now accounts for $50 \%$ of the total area of coral reefs in the region. Although the coral reefs in small island countries in the South Pacific are still in a relatively good state, some coral reef areas have shown signs of long-term decline, especially under the regional pressure brought about by global climate change and the impact of human activities. Thus, the survival of coral reefs in small island countries in the South Pacific has been greatly threatened [19]. According to assessments by current research, even if human beings stop all harmful activities, coral reefs will be greatly affected or even destroyed within several decades due to the influence of long-term climate change [46-48]. Additionally, if coral reefs continue to decline, biodiversity in offshore areas will likely decrease [49].

\subsubsection{Impact of Short-Term Climate Oscillations}

In addition to long-term trend changes, island countries in the Pacific region are also extremely vulnerable to short-term climate oscillations such as ENSO. El Nino refers to the phenomenon of abnormally warm sea surface temperatures in the equatorial Pacific, and La Nina refers to the phenomenon of abnormally cold sea-surface temperatures in the eastern and central equatorial Pacific. According to the ocean El Nino index (ONI) (Figure 7a), 2015 was a strong El Nino year (ONI > 2), and 2016-2018 was a weak La Nina year $(-1<\mathrm{ONI}<0)$. The sea-surface temperature dropped abnormally from 2015 to 2018 due to the alternation of El Nino years and La Nina years. Meanwhile the trend of rising sea levels had also stagnated and even dropped (Figure $7 \mathrm{~b}$ ).
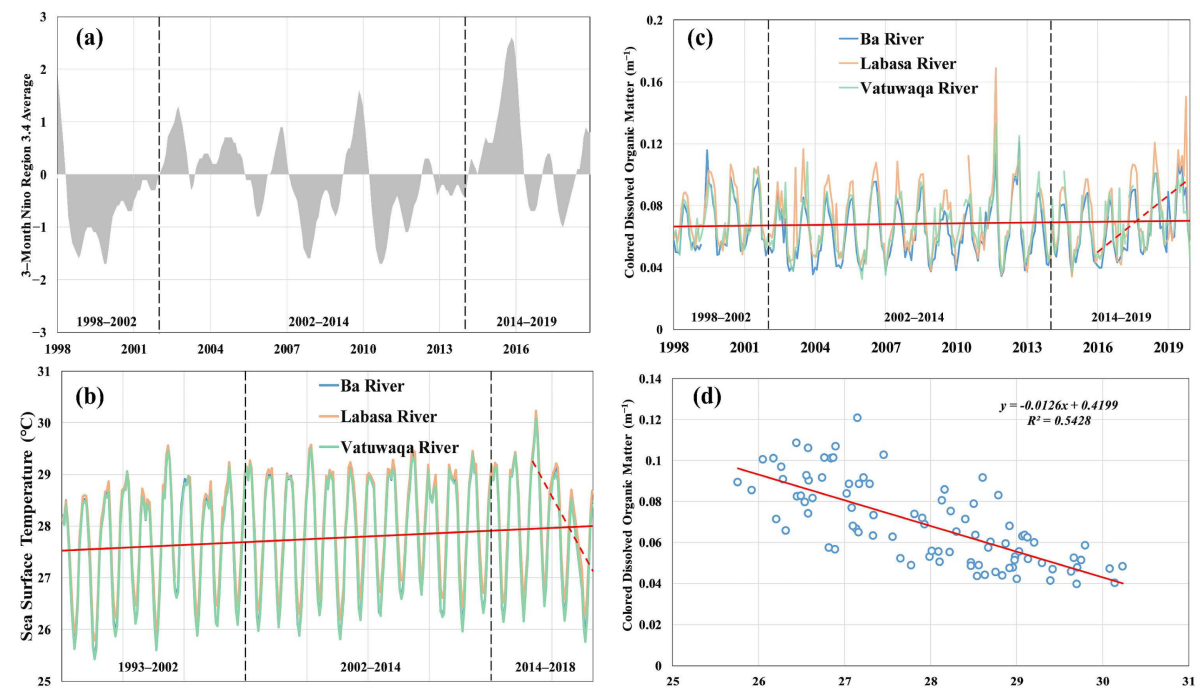

Figure 7. Ocean El Niño index, sea-surface temperature, colored dissolved organic matter changes, and correlation analysis of two kinds of ocean environmental parameters. (a) Ocean El Niño index; (b) Sea-surface temperature; (c) Colored dissolved organic matter (d) Correlation analysis between sea-surface temperature and colored dissolved organic matter (the Ocean El Niño Index (ONI) in (a) is the average sea-temperature anomaly in the Nino 3.4 area for three consecutive months. The threshold is subdivided into weak (0.5-0.9), medium (1.0-1.4), and strong (1.5-1.9) Harmony is very strong $(\geq 2.0)$, and the data come from the Climate Forecast Center of the National Meteorological Administration (website: https:/ / origin.cpc.ncep.noaa.gov/ (accessed on 4 September 2021)). The data of sea surface temperature and colored dissolved organic matter are from 2016 to 2018 in $(\mathbf{b}, \mathbf{c})$ ).

After 2016, the colored dissolved organic matter in three estuaries showed a significant increasing trend (Figure 7c). A negative correlation was found between sea-surface temperature and colored dissolved organic matter $\left(R^{2}=0.5428\right)$ (Figure $\left.7 d\right)$. Generally, the concentration of dissolved organic matter increases as the temperature decreases in the range of $20-75{ }^{\circ} \mathrm{C}$ [50]. The year $1998-1999$ was also a strong ENSO period, but, from 
current observation data, it did not show similar changes in the water environment as the ENSO events in 2015-2016; thus, more data are needed for a comprehensive analysis.

The occurrence of ENSO and other short-term climate oscillations events would further affect the offshore ecosystem. As was reported by Ellison and Fiu [16], coral reefs in the Fiji's surrounding waters experienced extensive bleaching in January 1999 and FebruaryJune 2000, respectively, which may be related to the stronger La Niña event at that time (also can be seen in Figure 7a), where coral reefs were exposed to extreme temperatures and bleaching occurred, which led to mass mortality of the coral algae, invertebrates, and fish that depend on coral reefs for survival.

Relevant studies further shown that while cold could cause acute stress on coral reefs and affect their survival to a certain extent, sustained long-term warming was more damaging to coral reefs [18]. From 1993 to 2015, the sea surface temperatures in the coastal waters around Fiji rose consistently, and in the last five years (2015-2019), the increasing rate of water temperature and sea level rises in the Fiji estuaries slowed down or even decreased due to the alternation of El Nino years and La Nina years (Figure 7a,b). This was beneficial to the recovery of coral reefs. Based on land-use-type results (Table 3), we also found that the coral reef area increased by $23.78 \%$ compared with the previous period.

In general, the occurrence of short-term climate oscillations events may cause drastic changes in the water environment around Fiji, including extreme changes in sea level, water temperature and the concentration of various substances in seawater. If these sudden climate oscillations events temporarily mitigate climate problems, they might be beneficial to various coastal ecosystems, but, in the context of continued global climate change, the frequency and intensity of extreme weather and events have been increasing [4]; that is, to a large extent, a serious threat to small island states in the South Pacific, such as Fiji, which are ecologically fragile.

\subsection{Impact of Human Activities}

\subsubsection{Impact on Land Use Types}

Fiji is rich in forest resources. As a major component of Fiji's economy and export industry, the forestry industry ranked third out of all industries in terms of its rate of contribution to Fiji's GDP [51]. However, from 2002 to 2014, Fiji's vegetation area decreased significantly, by $6.89 \%$, a total reduction of $987 \mathrm{~km}^{2}$. According to the published reports, the export trade income of Fiji's forest products from 2006 to 2014 showed a steady upward trend, reaching the maximum around 2014 [52]; in 2015, Fiji's exports of timber and wood products declined, but export income was still up to 110 million Fijian dollars [53]. The forestry industry's development was based on sufficient forest resources, and the increase in Fiji's forest products exports corresponds to increasing deforestation. In 2010, Fiji began to implement a new forestry policy, introducing and planting mahogany and Caribbean pine at a large scale, which restored the vegetation area to a certain extent and effectively reduced the bare land area [52]. As a result, the vegetation transfer gradually recovered from 2014 to 2019 , with a total of $1861.2 \mathrm{~km}^{2}$ of bare land converted into vegetation. By 2019 , the vegetation area in Fiji had recovered to $14,204 \mathrm{~km}^{2}$.

Due to Fiji's special geographical location and climate characteristics, it is more sensitive to the dynamic impact of land-sea interactions. These characteristics include its small area, lack of fresh water, poor self-recovery ability, fragile and sensitive ecological environment and greater vulnerability to human interference and destruction $[4,54]$. Vegetation in the drainage basin reduced soil erosion by runoff and had a strong impact on the transportation of sediments and nutrients $[55,56]$. The water transparency in three estuaries all showed a downward trend during 1998-2019 (Table 5 and Figure 6), indicating that the seawater had become turbid. At the same time, we found that the chlorophyll a concentration in each estuary was slightly higher from 2002 to 2013 than in other periods, and the water transparency was slightly lower than in other periods. The decrease in vegetation area led to an increase in the concentration of nutrient salt and suspended solids in runoff. 
From 2002 to 2014, a large area of bare land appeared in the west of Viti Levu and northeast of Vanua Levu in Fiji. This newly added bare land had a total area of $1460 \mathrm{~km}^{2}$ (Figure 8), which may be affected by the development of tourism and the increase in tourism infrastructure and facilities in addition to forestry development (Figure 9). Between 2000 and 2019, the number of international tourists visiting Fiji increased from 294,070 to 894,389 per year [57]. The rapid development of tourism brought great economic benefits to Fiji, but it also exerted pressure on the local ecological environment. The development of tourism and the increase in the number of tourists led to a large amount of vegetation being transformed into bare land and cities, and aggravated the pressures on the ecosystem.

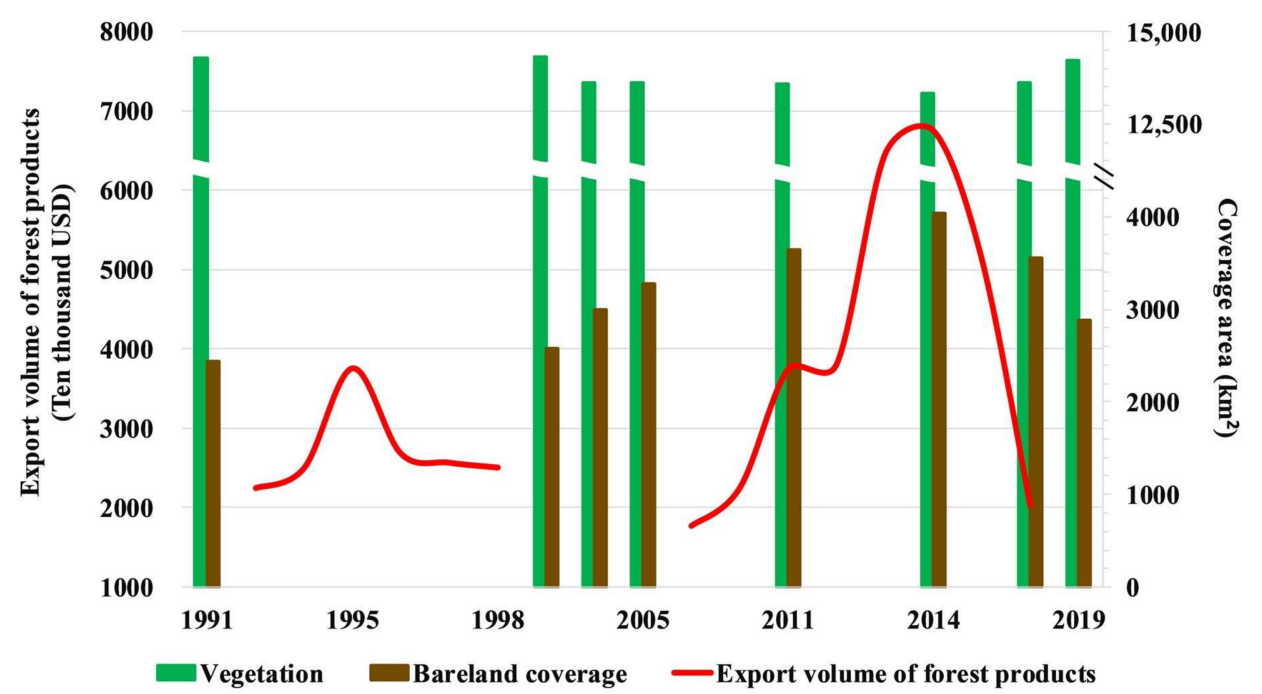

Figure 8. Changes in vegetation and bare land during 1991-2019 (data from Table 2), and Fiji's forest product exports (data from the literature and Food and Agriculture Organization of the United Nations (FAO) [52,53]).

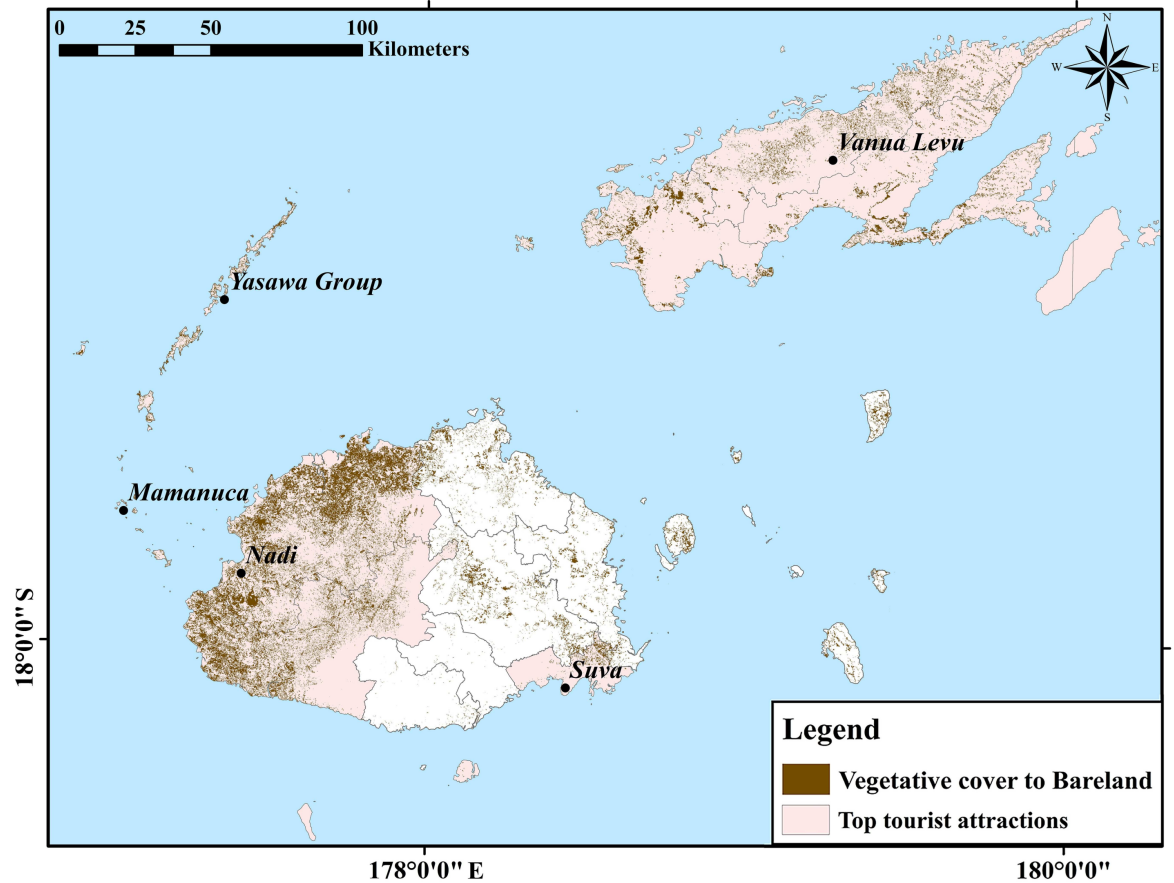

Figure 9. Distribution of bare land (data from Figure 5b) in Fiji in 2014 and the popular tourist attractions. Data come from the Economic and Commercial Counseling Office of the Chinese Embassy in Fiji [58]). 


\subsubsection{Impact on Coastal Ecology}

Besides the influence of climate change, coral reefs in Fiji's surrounding water are vulnerable and easily disturbed by human activities and land-use changes due to landsea interactions. For example, deforestation of coastal forests increased the suspended materials and nutrients in water through runoff, which had a direct and indirect impact on the growth and competition of algae and corals [59,60].

The area of coral reefs around Fiji decreased significantly from 2002 to 2014, with a reduction of $344 \mathrm{~km}^{2}$ (Table 2). Coral reefs decreased most significantly (51.13\%) surrounding Vanua Levu, and the concentration of colored dissolved organic matter and chlorophyll around Vanua Levu was higher than that around Viti Levu. This rising seawater turbidity $\left(\mathrm{a}_{\mathrm{CDOM}}>0, \mathrm{a}_{\mathrm{CHL}}>0, \mathrm{a}_{\mathrm{SDD}}<0\right)$ (Figure 6$)$ deteriorated the living environment of coral reefs, resulting in their decline.

Compared with the changes in land-use types and the corresponding drainage basin of runoff into the sea (Figures 10 and 11), it was found the bareland area of Vanua Levu of $668 \mathrm{~km}^{2}$ accounted for $16.59 \%$ of the total bare-land area, and the runoff area of $121 \mathrm{~km}^{2}$ accounted for $49.58 \%$ of the total runoff area. Bare land in western Viti Levu accounted for $63.38 \%$ of the total bare-land area (data in 2014), but had only $15.04 \%$ of the runoff area. East of Viti Levu, bare-land area accounted for $7.77 \%$ of the total area, but the runoff area into the sea was larger (33.59\%) than that in the west. Therefore, the decrease in coral reefs around Vanua Levu was associated with far greater bare land and runoff than around Viti Levu, and the coral reefs in the waters of Vanua Levu decreased by $51.13 \%$ of the total decrease area (Figures 10a and 11).

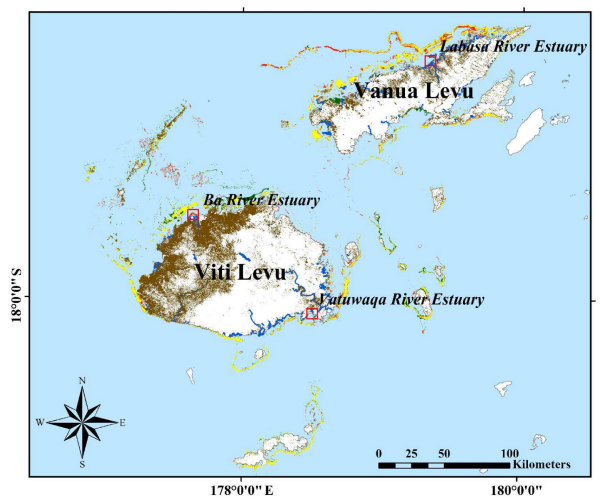

Legend

(a)

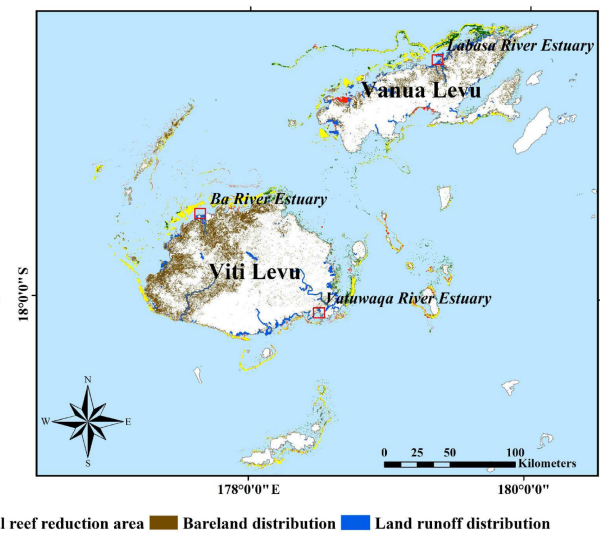

(b)

Figure 10. Area changes in coral reefs in Fiji. (a) change between 2002 and 2014; (b) change between 2014-2019. The distribution of bare land shows data for 2014 and 2019, respectively, in (a,b).

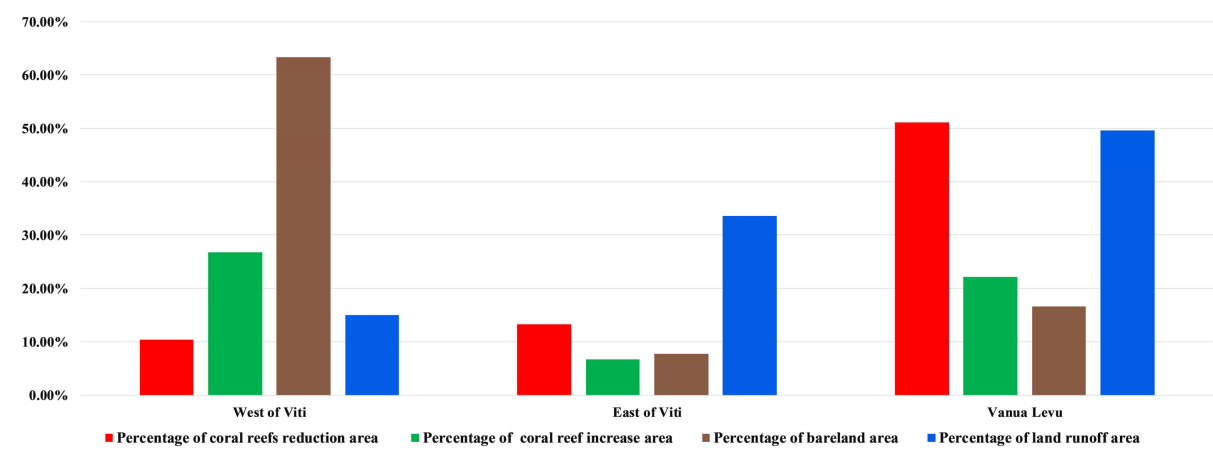

Figure 11. Area percentage histogram of bare land, land runoff area, and coral reef change area in surrounding waters of Viti Levu and Vanua Levu. In each area, both decreases and increases of coral reefs occurred in specific land-use type areas. 
After 2014, affected by ENSO and other short-term climate oscillations, the sea level and sea-surface temperature in the sea area adjacent to Fiji's estuary increased only slowly or even decreased (Figure 7a,b). It was also found that the bare-land area in Fiji decreased significantly in 2019 compared with 2014. The combined effect of land and sea changes improved the growth environment of coral reefs, and the ecosystem began to recover; for example, the coral reef area increased by $23.76 \%$ compared with 2014 . In the northern waters of Vanua Levu, coral reefs were obviously reduced in 2014, but began to recover (Figure 10b) after 2014, with the area's restored coral reef area of $277.51 \mathrm{~km}^{2}$ accounting for $39.86 \%$ of the total restored area in Fiji.

\subsection{Ecological Environment Pressure in Fiji and Other Small Island Countries}

In the last 30 years, Fiji has made good progress in terms of social and economic development. With the further aggravation of global climate issues and the increasing frequency of human activities, Fiji's fragile ecological environment has been severely challenged. Fiji's continued development is restricted by the reduction in vegetation area, the deterioration of water conditions in the sea area, and the continuous rise in seawater temperature and sea level. In response, Fiji has put forward a series of development policies, hoping to reduce the impact of global changes such as sea-surface temperature and rising sea level by building a climate change monitoring network, strengthening natural disaster forecasting and early warnings, regulating rivers, planting mangroves and realizing sustainable land use [61]. Fiji's ecosystem still faces many challenges and potential ecological risks. In terms of land, in order to restore the vegetation area, Fiji introduced and planted two exotic tree species, mahogany and Caribbean pine, after 2010. Although this move gradually restored the vegetation area of Fiji from 13,320 km² in 2014 to $14,204 \mathrm{~km}^{2}$, the large-scale introduction of exotic tree species is likely to destroy the diversity, stability, and sustainability of the local forest ecosystem. This is also an important potential threat to the forest ecosystem in Fiji. In terms of sea, rising sea-surface temperatures and sea-level height is still the main threat to Fiji. Although in 2015-2018, due to the impact of short-term climate oscillations, the sea surface temperature decreased abnormally, and the trend of rising sea levels had also stagnated and even dropped, which temporarily slowed down the impact of global climate change, it also led to the abnormal increase in colored dissolved organic matter and the decrease in water transparency in the waters around Fiji during this period (Figure 7). At the same time, this also reflects that Fiji's ecological environment response to short-term climate oscillations is sensitive and fragile. From the overall trend in recent decades, the sea temperature in the waters around Fiji has increased by about $0.3^{\circ} \mathrm{C}$, and the sea-level rise rate is still up to $4 \mathrm{~mm} / \mathrm{yr}$ (Figure 6a,b. Such environmental changes had a huge impact on small island countries such as Fiji. Based on current climate change trends, in the next 30 to 100 years, two types of ecosystems, coral reefs and mangroves, will be greatly damaged, seriously threatening the stability of local ecosystems and biodiversity, and even causing a series of negative effects such as shoreline retreat, seawater intrusion, and soil salinization.

Compared with inland areas, as one of the fastest and most sensitive interfaces of global change, and due to the various dynamic actions of land and sea, the relationship between land and sea ecosystems of islands became more intertwined. Thus, if one of them faces ecological problems, it could trigger an extensive and irreparable adverse chain reaction. Fiji's development depends to a great extent on the country's natural resources, such as coral reefs and mangroves. Excellent water quality will promote the development of tourism, and forest resources promote forestry industry development. A healthy balance between Fiji's land and sea ecological environments should be the basis for ensuring the sustainable exploitation of Fiji's natural resources. Once the ecological environment becomes unbalanced, it will further affect Fiji's social and economic development.

Many other countries face similar ecological and environmental problems to Fiji. The Alliance of Small Island States, which is composed of small island developing countries in the Pacific Ocean, Indian Ocean, and Atlantic Ocean, is one of the major groups that is 
most concerned about global climate change. Globally, these countries are most adversely affected by climate warming and face the greatest danger from climate change. These countries also face similar development challenges, such as small territory, remote geographical location, single economic development structure, lack of human and natural resources, and weak adaptability to natural disasters. Among them, Tonga, Marshall Islands, Kiribati and Tuvalu are already facing the negative impact and serious threat of global climate change, such as sea-level rise [15,42]. How to effectively deal with global climate change, reasonably control human activities and achieve sustainable development are the main problems to be solved in small island countries at this stage.

\section{Conclusions}

This study takes Fiji, one of the small island countries in the South Pacific, as a research case to understand the change in land-use, and trends of atmospheric and water environment in the surrounding waters of Fiji from 1991 to 2019 based on multi-source satellite data. According to the change in forest area in Fiji, it was divided into three stages: the first stage remained stable, followed by a decreasing stage, and a recovery in recent years. Through the long-term changes in sea and land ecological environment, we can understand the ecological environment pressure faced by small island countries.

From 1991 to 2002, Fiji's vegetation area was at a relatively high level, about 14,000 km², accounting for $73 \%$ of the total land coverage, whereas the bare-land area was relatively small, about $2500 \mathrm{~km}^{2}(13 \%)$, and the sea-level height, sea-surface temperature, and atmospheric carbon dioxide were relatively low.

From 2002 to 2014, the vegetation area fell to its lowest value, $13,320 \mathrm{~km}^{2}$, and the bareland area reached its highest value of $4030 \mathrm{~km}^{2}$ in 2014. In the same period, the chlorophylla concentration in three major estuaries and adjacent sea area lightly increased, and the water transparency was low. Coupled with the rising sea temperature, the area of coral reefs in the waters around Fiji shrank significantly, especially in the waters around Vanua Levu, where the bare-land area and land runoff were more distributed; the area of the coral reef decrease accounted for $51.13 \%$ of the total decreased area in this period. According to the analysis of island land-use types and water environment changes around the island, it could be found that the leading industries (human activity pressure), represented by forestry and tourism in Fiji, forced the vegetation to turn into bare land or city, resulting in a large reduction in vegetation and a large increase in bare land in Fiji from 2002 to 2014. Coupled with the erosion of runoff in the basin, a large number of nutrients and sediments entered the ocean with runoff, causing changes in the sea environment, including the increase in suspended matter and phytoplankton, the increase in seawater turbidity and the decrease in transparency, which may eventually affect or even destroy the marine ecological environment and ecological resources such as offshore coral reefs and mangroves.

From 2014 to 2019, under the influence of Fiji's new forestry policy, the vegetation area began to recover, and the coral reef area increased by $482 \mathrm{~km}^{2}$ during the same period. The rises in sea-surface temperature and sea-level height slowed down, but the colored dissolved organic matter increased and water transparency decreased. It was found that ENSO events may cause an abnormal decrease in sea-surface temperature and a decrease in the decomposition rate of colored dissolved organic matter, which would then increase the colored dissolved organic matter content and decrease the water transparency. Therefore, besides the long-term natural changes characterized here, short-term climate oscillations such as ENSO will also have a great impact on Fiji's offshore ecological environment.

In general, Fiji experienced three stages of environment change, which resulted from the multi-pressures of human activities and climate change. It is very important yo continually monitor the changes in the land and sea ecological environment in small island countries in the South Pacific, in order to understand the impact of global climate change and human activities and support the sustainable development of islands. 
Author Contributions: Conceptualization, B.Z., Y.B. and X.C.; methodology, B.Z. and X.H.; software, T.L.; validation, B.Z.; resources, X.C. and F.G.; data curation, F.G.; writing-original draft preparation, B.Z.; writing-review and editing, Y.B. and X.H.; visualization, B.Z. and T.L. All authors have read and agreed to the published version of the manuscript.

Funding: This study was supported by the National Key Research and Development Program of China (Grant \#2017YFA0603003), the National Natural Science Foundation of China (Grants \#41825014), and Zhejiang Talent Program (LR18D060001), Zhejiang Provincial Natural Science Foundation of China (2017R52001), and Key Special Project for Introduced Talents Team of Southern Marine Science and Engineering Guangdong Laboratory (Guangzhou) (GML2019ZD0602).

Institutional Review Board Statement: Not applicable.

Informed Consent Statement: Not applicable.

Data Availability Statement: Data available in a publicly accessible repository that does not issue DOIs. Landsat series data were downloaded from https:/ / earthexplorer.usgs.gov/ (accessed on 8 September 2019). The satellite data for the water environment were obtained from the Marine Satellite Online Analysis Platform (SatCO2), and can be found here: http:/ /www.satco2.com (accessed on 4 September 2021).

Acknowledgments: We thank SOED/SIO/MNR satellite ground station, satellite data processing \& sharing center, and marine satellite data online analysis platform (SatCO2) for their help with data collection and processing. We thank United States Geological Survey (USGS) (https:/ / earthexplorer. usgs.gov / (accessed on 8 September 2019)) for providing the Landsat series satellite data, European Space Agency (ESA) (https: / / www.oceancolour.org / (accessed on 4 September 2021)) for providing the CCI data set, NASA's SeaWiFS and MODIS/Aqua satellites (https: / oceancolor.gsfc.nasa.gov/ (accessed on 4 September 2021)) for providing the remote sensing reflectance data, Copernicus Marine Environmental Monitoring Center(CMEMS)(http: / / marine.copernicus.eu/services-portfolio/accessto-products / (accessed on 4 September 2021)) for providing the sea level anomaly products, the National Oceanic and Atmospheric Administration (NOAA)(https:/ / www.ncdc.noaa.gov/oisst/ data-access (accessed on 4 September 2021)) for providing the OISST data set, and National Oceanic and Atmospheric Administration (NOAA) (https:/ / www.esrl.noaa.gov/gmd/ccgg/carbontrack (accessed on 4 September 2021)) for providing the Carbon-track data set.

Conflicts of Interest: The authors declare no conflict of interest.

\section{Appendix A}

Table A1. Remote-sensing image detailed information.

\begin{tabular}{|c|c|c|c|c|c|c|c|c|}
\hline \multirow{2}{*}{$\begin{array}{l}\text { Path/Row } \\
\text { Satellite }\end{array}$} & \multicolumn{2}{|c|}{074071} & \multicolumn{2}{|l|}{074072} & \multicolumn{2}{|l|}{074073} & \multicolumn{2}{|l|}{075072} \\
\hline & Acquisition Time & $\begin{array}{c}\text { Cloud } \\
\text { Cover (\%) }\end{array}$ & Acquisition Time & $\begin{array}{c}\text { Cloud } \\
\text { Cover (\%) }\end{array}$ & Acquisition Time & $\begin{array}{c}\text { Cloud } \\
\text { Cover (\%) }\end{array}$ & Acquisition Time & $\begin{array}{c}\text { Cloud } \\
\text { Cover (\%) }\end{array}$ \\
\hline \multirow[t]{2}{*}{ Landsat-5 } & 11 July 1991 & 14 & 11 July 1991 & 30 & 28 August 1991 & 14 & 15 May 1991 & 37 \\
\hline & 19 September 2002 & 0 & 19 September 2002 & 0 & 19 September 2002 & 0 & 15 May 2000 & 6 \\
\hline \multirow{4}{*}{ Landsat-7 } & 19 May 2004 & 14 & 6 July 2004 & 12 & 19 May 2004 & 9 & 10 May 2004 & 1 \\
\hline & 9 July 2005 & 5 & 16 December 2005 & 2 & 9 July 2005 & 5 & 16 July 2005 & 1 \\
\hline & 11 August 2011 & 9 & 11 August 2011 & 2 & 11 August 2011 & 10 & 15 August 2010 & 7 \\
\hline & 24 June 2014 & 3.52 & 23 May 2014 & 19.56 & 11 October 2013 & 11.53 & 3 September 2014 & 1.4 \\
\hline \multirow{2}{*}{ Landsat-8 } & 3 October 2016 & 16.56 & 13 June 2016 & 7.99 & 3 August 2017 & 4.82 & 6 July 2016 & 0.64 \\
\hline & 22 June 2019 & 5.71 & 22 June 2019 & 3.98 & 22 June 2019 & 4.95 & 28 May 2019 & 0.84 \\
\hline
\end{tabular}

Table A2. Segmentation parameters.

\begin{tabular}{ccc}
\hline Segmentation Parameters & Explanation & Specific Parameters \\
\hline Segmentation scale & $\begin{array}{c}\text { Define the maximum standard deviation of the uniformity criterion of } \\
\text { the weighted image layer of the image object resulthe larger the scale } \\
\text { parameter value, the larger the result of the image object }\end{array}$ & 50 \\
Color factor & Image object result value & 0.8 \\
Shape factor & Texture consistency of image object results & 0.2 \\
Smoothness & Using shape criteria, consider smooth edges & 0.5 \\
Compactness & Use shape criteria to consider overall compactness & 0.5 \\
\hline
\end{tabular}




\section{References}

1. ONU. The Sustainable Development Goals Report 2020; United Nations: New York, NY, USA, 2020.

2. Jiang, K.-J. IPCC special report on $1.5^{\circ} \mathrm{C}$ warming: A starting of new era of global mitigation. Clim. Chang. Res. 2018, 14, 640-642. [CrossRef]

3. Peng, Z. Environmental Issues in the South Pacific Region and Island Countries' Environmental Diplomacy: Also on China's Response; Central China Normal University: Wuhan, China, 2012.

4. Leng, Y.S.; Sun, S.X.; Wang, Z.L.; Zhang, Z.H.; Zhou, M. Vulnerability analysis of island ecological environment and regulating measures. Coast. Eng. 2008, 27, 58-64. [CrossRef]

5. Taylor, S. The Vulnerability of Health Infrastructure to the Impacts of Climate Change and Sea Level Rise in Small Island Countries in the South Pacific. Health Serv. Insights 2021, 14, 11786329211020857. [CrossRef]

6. Shiming, W.; Yanfen, W. On the Historic Significance of Xi Jinping's Visit to the Pacific Island Countries. Frontiers 2015, 2015, 54-67, 87. [CrossRef]

7. Huang, B.; Ddeng, Y.; Zhang, X. Study on the Path and Direction of China-Fiji Climate Change Cooperation. J. South. China Sea Stud. 2018, 4, 107-114.

8. International Geosphere-Biosphere Programme; Stockholm (Sweden). Land-use and land-cover Change (LUCC). Implementation strategy:a core project of the international geosphere-biosphere programme and the international human dimensions programme on global environmental change. Glob. Chang. Rep. 1999, 20, 91-102.

9. Wang, X.; Bao, Y. Study on the Methods of Land Use Dynamic Change Research. Prog. Geogr. 1999, 18, 3-5. [CrossRef]

10. Yuan, F. Land-cover change and environmental impact analysis in the Greater Mankato area of Minnesota using remote sensing and GIS modelling. Int. J. Remote Sens. 2008, 29, 1169-1184. [CrossRef]

11. Kamh, S.; Ashmawy, M.; Kilias, A.; Christaras, B. Evaluating urban land cover change in the Hurghada area, Egypt, by using GIS and remote sensing. Int. J. Remote Sens. 2012, 33, 41-68. [CrossRef]

12. Sealey, K.S. Large-scale ecological impacts of development on tropical islands systems: Comparison of developed and undeveloped islands in the central Bahamas. Bull. Mar. Sci. 2004, 75, 295-320. [CrossRef]

13. McCubbin, S.G.; Pearce, T.; Ford, J.D.; Smit, B. Social-ecological change and implications for food security in Funafuti, Tuvalu. Ecol. Soc. 2017, 22, 53. [CrossRef]

14. Attrill, M.J.; Rundle, S.D. Ecotone or Ecocline: Ecological Boundaries in Estuaries. Estuar. Coast. Shelf Sci. 2002, 55, 929-936. [CrossRef]

15. Devlin, M.; Smith, A.; Graves, C.A.; Petus, C.; Lyons, B.P. Baseline assessment of coastal water quality, in Vanuatu, South Pacific: Insights gained from in-situ sampling. Mar. Pollut. Bull. 2020, 160, 111651. [CrossRef]

16. Ellison, J.; Fiu, M. Vulnerability of Fiji's Mangroves and Associated Coral Reefs to Climate Change; World Wild Fund (WWF): Gland, Switzerland, 2010. Available online: http:/ / ecite.utas.edu.au/ 66889 (accessed on 4 September 2021).

17. Gilby, B.L.; Olds, A.D.; Connolly, R.M.; Stevens, T.; Schlacher, T.A. Optimising Land-Sea Management for Inshore Coral Reefs. PLoS ONE 2016, 11, e0164934. [CrossRef]

18. Woesik, R.V.; Köksal, S.; Ünal, A.; Cacciapaglia, C.W.; Randall, C.J. Predicting coral dynamics through climate change. Sci. Rep. 2018, 8, 17997. [CrossRef] [PubMed]

19. Chin, A.; Lison de Loma, T.; Reytar, K.; Planes, S.; Gerhardt, K.; Clua, E.; Burke, L.; Wilkinson, C. Status of Coral Reefs of the Pacific and Outlook: 2011; Global Coral Reef Monitoring Network: New York, NY, USA, 2011.

20. Government of Fiji. Rebuilding Confidence for Stability and Growth for a Peaceful, Prosperous Fiji: Strategic Development Plan 2003-2005; Government of Fiji: Fiji, UK, 2002.

21. Ministry of Foreign Affairs of the People's Republic of China. Overview of Fiji. Available online: https://www.fmprc.gov.cn/ web /gjhdq_676201/gj_676203/dyz_681240/1206_681342/1206x0_681344/ (accessed on 27 June 2021).

22. Bai, Y.; Pan, D.; He, X.; Gong, F. The quasi-analytic remote sensing algorithm of CDOM in the China Yellow Sea and East Sea. In Proceedings of the Geoinformatics 2008 and Joint Conference on GIS and Built Environment: Classification of Remote Sensing Images, Guangzhou, China, 7 November 2008; SPIE: Bellingham, WA, USA, 2008; pp. 714711-714718.

23. Bai, Y.; Pan, D.; Cai, W.-J.; He, X.; Wang, D.; Tao, B.; Zhu, Q. Remote sensing of salinity from satellite-derived CDOM in the Changjiang River dominated East China Sea. J. Geophys. Res. Ocean. 2013, 118, 227-243. [CrossRef]

24. Lee, Z.P.; Carder, K.L.; Steward, R.G.; Peacock, T.G.; Davis, C.O.; Patch, J.S. An empirical algorithm for light absorption by ocean water based on color. J. Geophys. Res. Ocean. 1998, 103, 27967-27978. [CrossRef]

25. He, X.; Bai, Y.; Chen, C.-T.A.; Hsin, Y.-C.; Wu, C.-R.; Zhai, W.; Liu, Z.; Gong, F. Satellite views of the episodic terrestrial material transport to the southern Okinawa Trough driven by typhoon. J. Geophys. Res. Ocean. 2014, 119, 4490-4504. [CrossRef]

26. He, X.; Pan, D.; Bai, Y.; Wang, T.; Chen, C.-T.A.; Zhu, Q.; Hao, Z.; Gong, F. Recent changes of global ocean transparency observed by SeaWiFS. Cont. Shelf Res. 2017, 143, 159-166. [CrossRef]

27. He, X.Q.; Pan, D.L.; Mao, Z.H.; Zhu, Q.K. The study on the inversing model of water transparency using the SeaWiFS data. Acta Oceanol. Sin. 2004, 26, 55-62. [CrossRef]

28. Ducet, N.; Le Traon, P.Y.; Reverdin, G. Global high-resolution mapping of ocean circulation from TOPEX/Poseidon and ERS-1 and -2. J. Geophys. Res. Ocean. 2000, 105, 19477-19498. [CrossRef] 
29. Le Traon, P.Y.; Nadal, F.; Ducet, N. An Improved Mapping Method of Multisatellite Altimeter Data. J. Atmos. Ocean. Technol. 1998, 15, 522-534. [CrossRef]

30. Wang, Y.; Hou, T.; Zhang, R.; Qian, L.; Wang, F.; Long, Q. Prediction modeling of extreme sea level based on dynamic extreme value theory and Copula function. Ocean. Eng. 2016, 46, 62-70. [CrossRef]

31. Banzon, V.; Smith, T.M.; Chin, T.M.; Liu, C.Y.; Hankins, W. A long-term record of blended satellite and in situ sea-surface temperature for climate monitoring, modeling and environmental studies. Earth Syst. Sci. Data 2016, 8, 165-176. [CrossRef]

32. Loveland, T.R.; Reed, B.C.; Brown, J.F.; Ohlen, D.O.; Zhu, Z.; Yang, L.; Merchant, J.W. Development of a global land cover characteristics database and IGBP DISCover from $1 \mathrm{~km}$ AVHRR data. Int. J. Remote Sens. 2000, 21, 1303-1330. [CrossRef]

33. Olson, J.S.; Watts, J.A.; Allison, L.J. Major World Ecosystem Complexes Ranked by Carbon in Live Vegetation: A Database; Oak Ridge National Lab: Oak Ridge, TN, USA, 1985.

34. Peters, W.; Jacobson, A.R.; Sweeney, C.; Andrews, A.E.; Conway, T.J.; Masarie, K.; Miller, J.B.; Bruhwiler, L.M.P.; Pétron, G.; Hirsch, A.I.; et al. An atmospheric perspective on North American carbon dioxide exchange: CarbonTracker. Proc. Natl. Acad. Sci. USA 2007, 104, 18925. [CrossRef] [PubMed]

35. Peters, W.; Miller, J.B.; Whitaker, J.; Denning, A.S.; Hirsch, A.; Krol, M.C.; Zupanski, D.; Bruhwiler, L.; Tans, P.P. An ensemble data assimilation system to estimate $\mathrm{CO} 2$ surface fluxes from atmospheric trace gas observations. J. Geophys. Res. Atmos. Ournal Geophys. Res. Atmos. 2005, 110. [CrossRef]

36. United States Geological Survey. Landsat 7. Available online: https://www.usgs.gov/core-science-systems/nli/landsat/landsat7?qt-science_support_page_related_con=0\#qt-science_support_page_related_con (accessed on 27 June 2021).

37. Zhu, H.Y.; Li, X.B.; He, S.J. Spatio-temporal change of land use in Bohai Rim. Acta Geogr. Sin. 2001, 56, 260-267. [CrossRef]

38. Liu, J. Study on National Resources \& EnvironmentSuvey and Dynamic Monitoring Using Remote Sensing. J. Remote Sens. 1997, 1, 225-230. [CrossRef]

39. Liu, J.; Buhe, A. Study on Spatial-Temproal Feature of Modern Land-Use Change in China: Using Remote Sensing Techniques. Quat. Sci. 2000, 20, 229.

40. Micheal, O.; Bruce, G.; Hinkel, J.; Roderik, V.D.W.; Frederikse, T. Sea Level Rise and Implications for Low Lying Islands, Coasts and Communities; CATIE: Toronto, ON, USA, 2019.

41. Yu, J. Study on Climate Governance Cooperation between China and the South Pacific Island Countries under the Global Climate Governance Pattern; Central China Normal University: Wuhan, China, 2019.

42. Ellison, J.C. How South. Pacific Mangroves May Respond to Predicted Climate Change and Sea-Level Rise. In Climate Change in the South Pacific: Impacts and Responses in Australia, New Zealand, and Small Island States; Springer: Berlin/Heidelberg, Germany, 2000.

43. Saintilan, N.; Khan, N.; Ashe, E.; Kelleway, J.; Rogers, K.; Woodroffe, C.D.; Horton, B.J.S. Thresholds of mangrove survival under rapid sea level rise. Science 2020, 368, 1118-1121. [CrossRef] [PubMed]

44. Facility, G.E. Valuing the global environment-Actions \& investments for a 21st century. East. Afr. Agric. For. J. 1998, 12, 342-349. [CrossRef]

45. Raven, J.; Caldeira, K.; Elderfield, H.; Hoegh-Guldberg, O.; Liss, P.; Riebesell, U.; Shepherd, J.; Turley, C.; Watson, A. Ocean Acidification Due to Increasing Atmospheric Carbon Dioxide; The Royal Society: London, UK, 2005.

46. Spalding, M.D.; Brown, B.E. Warm-water coral reefs and climate change. Science 2015, 350, 769-771. [CrossRef]

47. Hughes, T.P.; Baird, A.H.; Bellwood, D.R.; Card, M.; Connolly, S.R.; Folke, C.; Grosberg, R.; Hoegh-Guldberg, O.; Jackson, J.B.C.; Kleypas, J.; et al. Climate Change, Human Impacts, and the Resilience of Coral Reefs. Science 2003, 301, 929-933. [CrossRef]

48. Hughes, T.P.; Anderson, K.D.; Connolly, S.R.; Heron, S.F.; Kerry, J.T.; Lough, J.M.; Baird, A.H.; Baum, J.K.; Berumen, M.L.; Bridge, T.C.; et al. Spatial and temporal patterns of mass bleaching of corals in the Anthropocene. Science 2018, 359, 80-83. [CrossRef] [PubMed]

49. De'ath, G.; Fabricius, K. Water quality as a regional driver of coral biodiversity and macroalgae on the Great Barrier Reef. Ecol. Appl. 2010, 20, 840-850. [CrossRef] [PubMed]

50. Cui, Z.; Liu, W.; Zhao, N.; Zhang, Y.; Liu, J.; Li, H.; Wei, Q.; Yang, L. The Influence of Temperature Change on Determined Concentrations of Dissolved Organic Matter in Water. Spectrosc. Spectr. Anal. 2006, 26, 1127-1129. [CrossRef]

51. Leslie, A.; Tuinivanua, O. Fiji Forestry Outlook Study; FAO: Bangkok, Thailand, 2010.

52. Li, W.; He, S.; Pan, Y.; Shen, L. Comparison and Analysis of Forestry Development in Papua New Guinea, the Philippines and Fiji. World For. Res. 2019, 32, 86-91. [CrossRef]

53. Food and Agriculture Organization of the United Nations. Forestry Production and Trade. Available online: http://www.fao. org/faostat/en/\#data/FO/visualize (accessed on 7 June 2021).

54. Zhang, Y. China's strategic choice in the South Pacific: Perspective, motivation and path. Contemp. World Soc. 2016, 5, 131-139.

55. McKergow, L.A.; Weaver, D.M.; Prosser, I.P.; Grayson, R.B.; Reed, A.E.G. Before and after riparian management: Sediment and nutrient exports from a small agricultural catchment, Western Australia. J. Hydrol. 2003, 270, 253-272. [CrossRef]

56. Olley, J.; Burton, J.; Hermoso, V.; Smolders, K.; McMahon, J.; Thomson, B.; Watkinson, A. Remnant riparian vegetation, sediment and nutrient loads, and river rehabilitation in subtropical Australia. Hydrol. Process. 2015, 29, 2290-2300. [CrossRef]

57. Fiji Bureau of Statistics. Visitor Arrivals Statistics; Fiji Bureau of Statistics: Fiji, UK, 2021. 
58. Economic and Commercial Office of the Embassy of the People's Republic of China in the Republic of Fiji. Fiji is Rich in Tourism Resources with Considerable Development Trend. Available online: https://www.statsfiji.gov.fj/statistics/tourism-andmigration-statistics / visitor-arrivals-statistics.html (accessed on 27 June 2021).

59. McCook, L.J. Macroalgae, nutrients and phase shifts on coral reefs: Scientific issues and management consequences for the Great Barrier Reef. Coral Reefs 1999, 18, 357-367. [CrossRef]

60. Nyström, M.; Folke, C.; Moberg, F. Coral reef disturbance and resilience in a human-dominated environment. Trends Ecol. Evol. 2000, 15, 413-417. [CrossRef]

61. Chaudhury, M. A Review of Climate Change Impacts, Adaptation Practices and Policies, and Relevant Institutions in Fiji; United Nations Framework Convention on Climate Change: Bonn, Germany, 2015. 